\title{
ICT for socio-economic development: A citizens' perspective
}

By: Prashant Palvia, Naveed Baqir, and Hamid Nemati

Palvia, Prashant; Baqir, Naveed; Nemati, Hamid. ICT for socio-economic development: A citizens' perspective, Information and Management 55(2) (2018) 160-176.

https://doi.org/10.1016/j.im.2017.05.003

\section{c) (i) (9)}

EY No No This work is licensed under a Creative Commons AttributionNonCommercial-NoDerivatives 4.0 International License.

\section{$* * *$ @ 2017 Elsevier B.V. Reprinted with permission. This version of the document is not the version of record. ***}

\section{Abstract:}

There is a widespread belief that information and communication technologies (ICTs) can play a significant role in the socio-economic development of a developing country. ICT has the potential to affect many aspects of economic and societal activities such as GDP growth, employment, productivity, poverty alleviation, quality of life, education, and healthcare. While the literature provides a myriad of definitions and elements of socio-economic development, the focus tends to be on theoretical conceptualizations from various disciplines and impacts from isolated individual projects. In particular, the impact of ICT on socio-economic development has not been carefully examined from the viewpoint of the ultimate stakeholder, the citizens of a country, who are the final consumers of the technology. This study fills this gap by focusing on the citizens' view in describing ICT-driven socio-economic development in a developing country. A theoretical framework influenced by the "capabilities approach" was developed to guide this research, and the interpretive stance was used to conduct the study. More specifically, the narrative research method, which is seldom used in IS research but is appropriate for this study, was used. Narratives allow deeper and profound insights into social representations and participants' beliefs about the role of ICT in socio-economic development. Using this methodology, a model of the impact dimensions of socio-economic development is presented.

Keywords: Socio-economic development | ICT for development | Capabilities approach | Functionalities | Impacts | Narrative research

\section{Article:}

\section{Introduction}

Information and communication technologies (ICTs) are often presented as factors in global socio-economic development. There is a widespread optimistic view that ICT can play a significant role in economic development, GDP growth, capacity development and employment, productivity and organizational restructuring, poverty alleviation, and democratic participation of citizens [1], [2], especially in the context of developing countries. ICTs are also expected to have an important impact on the transparency and responsiveness of governmental agencies, education 
and healthcare opportunities, cultural creativity, and social integration of individuals with diverse cultural backgrounds. At the same time, socio-economic development in a developing nation has many stakeholders, e.g., the government and governmental agencies; non-governmental agencies (NGOs); private firms; foreign and international agencies, countries, and firms; investors; political groups; and, ultimately, the citizens of the country.

The concept of socio-economic development is not new to information systems (IS) researchers. It was first referred to in an article on "computers and the frustrated chief executive" [3]. Hardy's research [4] on telephones for economic development was another step toward the realization of the importance of ICT in socio-economic development. Later, Orlikowski and Iacono [5] referred to information technology as the centrality in everyday socio-economic life. Puri [6] discussed the role of ICT in creating a better world and referred to socio-economic development as a means to advance the less developed countries. Hsieh et al. [7] analyzed behavior models of the socio-economically advantaged and disadvantaged to understand the digital divide. Chaudhuri [8] found that ICT for development (ICT4D) schemes around the world fail despite active support; the one exception being the diffusion of mobile phones. More recently, Liew et al. [9] indicated that religion, ethnicity, language, gender, and education are significant factors moderating the adoption, perception, and use behavior of Facebook in a developing country.

While the literature provides a myriad of elements and examples of socio-economic development and impact, the focus tends to be on theoretical conceptualizations from various disciplines and impacts from isolated individual projects. As alluded to earlier, socio-economic development in a nation has many stakeholders, e.g., the government and governmental agencies, NGOs, private firms, foreign and international agencies, internal and external firms, investors, political groups, foreign countries, and, ultimately, the citizens of the country. According to the stakeholder theory [10], there are several stakeholders in business with cooperative and competing interests, and their views must be incorporated to develop a balanced perspective. We argue that the same is true for understanding socio-economic development. In particular, the impact of ICT on socioeconomic development has not been carefully examined from the viewpoint of the ultimate stakeholder, the citizens of a country, who are the final arbiters of the technology. They are important stakeholders, if not the most important stakeholders, in socio-economic development. Their views must be examined carefully to gain a more comprehensive understanding of the ultimate impact of ICT on socio-economic development and to inform the other stakeholders of the real possibilities. In fact, the Nobel Prize winner Amartya Sen professes that "it is the people directly involved who must have the opportunity to participate in deciding what should be chosen, not local elites (political or religious) or cultural experts (domestic or foreign) [11].

Our goal in this research is to examine ICT-based socio-economic development in a developing country from the viewpoint of the citizens of the country. More specifically, our research questions/objectives are the following: (1) What are the citizens' views on the impact of ICT on socio-economic development? and (2) Can these views be classified into specific dimensions reflecting domains of activities? To accomplish this goal and the objectives, an interpretive research approach using citizens' qualitative narratives was deemed most appropriate as it provided the most suitable tools for this endeavor. Narratives of citizens about what they considered socio-economic development were collected in three phases in a developing country. 
The analysis of these narratives yielded a grounded model of the impact of ICT on socioeconomic development.

Our research contributes to theory and practice in a number of ways. First and foremost, it provides an empirical 'grassroots' citizens' view of ICT-based socio-economic development. As we argue, citizens are important stakeholders in socio-economic development and perhaps the most important ones. In this paper, we first build a theoretical framework of ICT's impacts on socio-economic development. This framework is an adaptation and extension of Sen's "capabilities approach" [11] (CA) and applies it in the context of ICT. The framework presented herein by itself would provide numerous opportunities to build on our work and further enhance and extend it. The framework sensitizes our work and is the guiding force leading to empirically driven findings and a model of realized ICT impacts. On a practical level, various other stakeholders, e.g., the government, NGOs, and private corporations would know what ICT-based initiatives work (and those that do not work) and what their consequences are, both intended and unintended, so that they can use their limited resources in more effective ways.

\section{Literature review}

To define socio-economic development, it is appropriate to first understand development and a closely associated and sometimes interchangeably used term growth. However, the distinction between these two terms becomes apparent when the concept of horizontal expansion and vertical advancement is considered [12]. Development is defined as progressive course of growth [13]. Growth is horizontal expansion in which, for example, service area for ICT might be increased by putting more cellular towers, laying more network cables, or allowing people in far off places to connect to Internet hubs. This is sometimes referred to as infrastructure development or growth. Development represents vertical advancement where society moves from lesser to greater levels of energy efficiency, quality, complexity, comprehension, creativity, enjoyment, and accomplishment [12].

Several theories explain the process of development in developing countries, e.g., the modernization theory [14], dependency theory [15], world systems theory [16], state theory [17], economic development theory [18], comprehensive theory of social development [12], and social development theory [19], [1], [20]. Social development, in its simplest form, refers to opportunities for education; social interactions; and evolution of social customs, fashion, and trends [21]. Economic development, on the other hand, means creation of (better paying) jobs, widespread and sustained increase in living standards, and accelerated economic activities [21]. The World Bank defines economic development as "qualitative change and restructuring in a country's economy in connection with technological and social progress." The main indicator of economic development is increasing GNP per capita (or GDP per capita) [22]. Table 1 provides definitions of socio-economic development from different disciplines.

With regard to the literature related to ICT for socio-economic development, research generally falls into two areas. The first area includes conceptual and philosophical exercises, which on occasion provide or are based on anecdotal evidence. For example, Orlikowski and Iacono [5] referred to information technology as the centrality in everyday socio-economic life. 
Puri [6] discussed the role of ICT in creating a better world and referred to socio-economic development as a means to advance the less developed countries. Hsieh et al. [7] analyzed behavior models of the socio-economically advantaged and disadvantaged to understand the digital divide. Thapa and Sæbø [32] examined 80 articles to identify various theories and the role of ICT in development. Gigler [33] in his book discussed various topics related to ICT for development, including the role of ICT in individual empowerment and four informational capabilities, i.e., information literacy, ICT capability, communications capability, and content capability.

Table 1. Definitions of socio-economic development from various academic disciplines.

\begin{tabular}{|c|c|c|}
\hline Discipline & What is Socio-economic Development? & Literature \\
\hline \multirow[b]{2}{*}{ Economics } & $\begin{array}{l}\text { Socio-economic development is a "potpourri of economic, social, cultural and political } \\
\text { forces" }\end{array}$ & {$[23]$} \\
\hline & $\begin{array}{l}\text { Various dimensions of socio-economic development that are considered vital include } \\
\text { grassroots development such as entitlement, empowerment, entrepreneurship, well-being } \\
\text { and sustainability. Poverty is viewed as vulnerability and lack of voice, power, and } \\
\text { representation }\end{array}$ & {$[24]$} \\
\hline \multirow{2}{*}{ Sociology } & $\begin{array}{l}\text { Individual income as well as contextual income such as GDP, education, information, } \\
\text { freedom of choice, social stability, autonomy, and social values such as power, security, } \\
\text { achievement, hedonism (aspiration), stimulation, self-direction, conformism/tradition, and } \\
\text { benevolence/goodness }\end{array}$ & {$[25]$} \\
\hline & $\begin{array}{l}\text { development in income, education, human capabilities, politics, culture, ecology, nutrition, } \\
\text { health, life expectancy, personal dignity, freedom of association, personal safety and } \\
\text { freedom from fear of physical harm, and the extent of participation in the civil society part } \\
\text { of socio-economic development }\end{array}$ & {$[19]$} \\
\hline \multirow[b]{2}{*}{$\begin{array}{l}\text { Political } \\
\text { Science }\end{array}$} & Broad and equitable improvements in material and social welfare of people & {$[26]$} \\
\hline & $\begin{array}{l}\text { Economic power, wealth, income, direct and indirect economic benefits in the form of } \\
\text { (better paying) jobs, better living standards, and accelerated economic activities }\end{array}$ & [21] \\
\hline \multirow[t]{2}{*}{ Geography } & $\begin{array}{l}\text { Natural resources, income, infrastructure, health, poverty, infant mortality, child nutrition, } \\
\text { inequality, and social cohesion combined explain the socio-economic development of a } \\
\text { region, country, and society. Geography deeply impacts socio-economic development. It } \\
\text { becomes an important and interesting concept when the impact of altitude, urbanization, } \\
\text { rainfall, distance to market, sea, rivers, population density, quality of public } \\
\text { administration, and general level of health and diseases are discussed in relation socio- } \\
\text { economic development. }\end{array}$ & {$[27]$} \\
\hline & $\begin{array}{l}\text { Issues such as social capital, civil society, and participatory development and economic } \\
\text { development }\end{array}$ & {$[28]$} \\
\hline Climatology & $\begin{array}{l}\text { Socio-economic development is defined as complex social challenge including life- } \\
\text { expectancy, educational achievement, quality of governance (political stability, level of } \\
\text { corruption), and disparities in per capita income. }\end{array}$ & {$[29]$} \\
\hline $\begin{array}{l}\text { Medical } \\
\text { Science }\end{array}$ & $\begin{array}{l}\text { Socio-economic development is considered means of inequality in access to healthcare, } \\
\text { service use, and outcomes. Medical science's view of socio-economic development } \\
\text { includes understanding of the poverty levels, social justice (and inequalities), education, } \\
\text { health care access, service, use, and ability to pay }\end{array}$ & {$[30]$} \\
\hline \multirow{2}{*}{$\begin{array}{l}\text { Information } \\
\text { Systems }\end{array}$} & $\begin{array}{l}\text { Education and income levels are used to define socio-economically advantaged and } \\
\text { disadvantaged. }\end{array}$ & {$[7]$} \\
\hline & $\begin{array}{l}\text { Socio-economic development dimensions include social wellbeing, economic growth, } \\
\text { political wellbeing, and physical environment }\end{array}$ & {$[31]$} \\
\hline
\end{tabular}

The second area includes specific ICT projects and their impact on development. While there are many such efforts, some representative examples are provided. Early on, Hardy's research [4] on telephones provided support for the importance of ICT in socio-economic development. 
Madon [34] examined the impact of e-government initiatives on development using Amartya Sen's CA [11]. Chaudhuri [8] found that ICT4D schemes around the world fail despite active support; the one exception being the diffusion of mobile phones. More recently, [9] indicated that religion, ethnicity, language, gender, and education are significant factors moderating the adoption, perception, and use behavior of Facebook in a developing country. There have been a few literature surveys on ICT for development in the last decade that include many such projects, and the reader is directed to them, e.g., Madon [34], Avgerou [35], and Thapa and Sæbø [32].

What is lacking is any systematic effort to evaluate the overall impact of ICT on socio-economic development, especially from the perspective of the citizens of a country. What comes closest is Madon's theoretical model [31], which attempts to define the concept of socio-economic development in developing countries and its dimensions within the context of Internet growth. She identified four dimensions of socio-economic development: social wellbeing, economic growth, political wellbeing, and physical environment. Several application areas are identified within these dimensions, i.e., economic productivity, health, education, poverty alleviation and empowerment, democracy, and sustainable development (Fig. 1). Note that Madon's model was a conceptual exercise and was not empirically validated. Later, we will use her model as a benchmark to compare our results with.

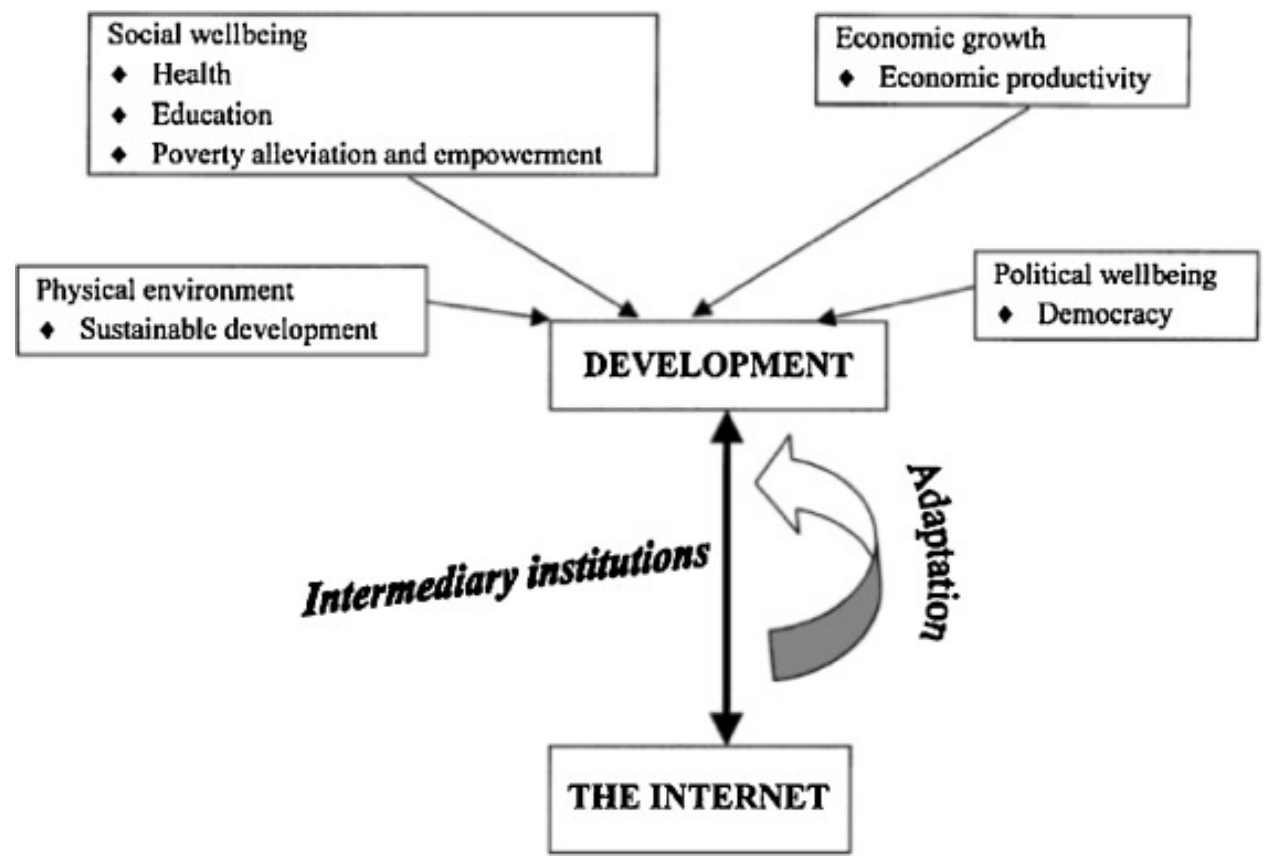

Fig. 1. Internet and Socio-economic Development. Source: [31].

\section{ICT, socio-economic development, and capabilities approach}

Our goal is to examine ICT-based socio-economic development from the perspective of the citizens of a country. They are the final consumers of technology and thus an important stakeholder among a myriad of stakeholder with cooperative and competing interests [10]. It can be argued that they are the most important stakeholders as they bear the final impact, and their views cannot be ignored. 
The seminal writings of Amartya Sen [11] and Martha Nussbaum [36] provide an important theoretical background for our study. Amartya Sen [11], in his prolific and inspiring writings, developed the concept of human capabilities, often referred to as the 'Capability Approach' or the "CA framework." Sen developed and continually refined this approach over three decades. In related development, Nussbaum [36] argued that human rights are entitlements that belong to all human beings and include things such as rights to resources, opportunities, and fair treatment. These deserve to be both provided and protected. Later she concluded that the language of rights, while noteworthy, is not particularly informative in the context of development and advocated the CA for its importance in welfare and quality of life.

The major components of the CA are "capabilities" and "functionings." The impetus for the CA is based on the critique of opulence-based and utilitarian approaches that focus on income, goods and services, and physical artifacts, which are the means to achieve certain ends. Capabilities, on the other hand, refer to the many opportunities available to individuals to pursue a life that he/she values. In this sense, the word "capability" used by Sen differs from its everyday use, such as skills and abilities of an individual. Functionings are the ends, which are the "beings and doings" of an individual and may include such things as healthcare, education, communication, etc. According to the CA framework, functionings are realized achievements and fulfilled expectations and capabilities are the freedoms and opportunities to achieve the functionings. Several researchers have extended the CA framework in the context of ICT for development. Notable works include those of Madon [34], Zheng [37], and Thapa and Sæbø [32]. Specifically, Zheng [37] and Thapa and Sæbø [32] have developed frameworks based on the representation of the CA framework provided by Robeyns [38].

The CA framework augmented by additional theories sensitizes and provides the philosophical basis for our interpretive study and the initial guiding force. In fact, Walsham [39] discussed the importance of developing a philosophical basis for the use of theories in interpretive research. He points out that a "guiding" theory matters, irrespective of philosophical perspective, and discusses three distinct uses of theory: as an initial guide to design and data collection, as part of an iterative process of data collection and analysis, and as final product of the research [40]. According to Walsham [39], the motivation for the use of a guiding theory early on during an interpretive case study is to allow the researcher to "create an initial theoretical framework which take account of previous knowledge, and which creates a sensible theoretical basis" to inform future studies. This view is consistent with the structural-pragmatic-situational (SPS) approach presented in Pan and Tan [41]. According to SPS, conceptualization of the phenomenon under study should lead to "constructing and extending the theoretical lens" through which the study will proceed. Concepts and underlying principles of the CA provide the theoretical framework to critically evaluate the unbiased account of citizens' narratives about their interaction with and use of ICT. According to CA, individuals vary in their abilities to convert a given resource (e.g., the capabilities provided by mobile phones) into valuable functionings ("beings" and "doings"). Analyzing ICT for socio-economic development through the prism of the CA allows for a new conceptualization of ICT to emerge.

Using the CA as the primary guide for this interpretive study, we extend it with additional related theories. The resulting theoretical framework is shown in Fig. 2 and described below. While the 
framework is a starting point for our study and a guiding force, it may be used in future studies to develop interesting research questions, which may be probed in detail with greater precision.

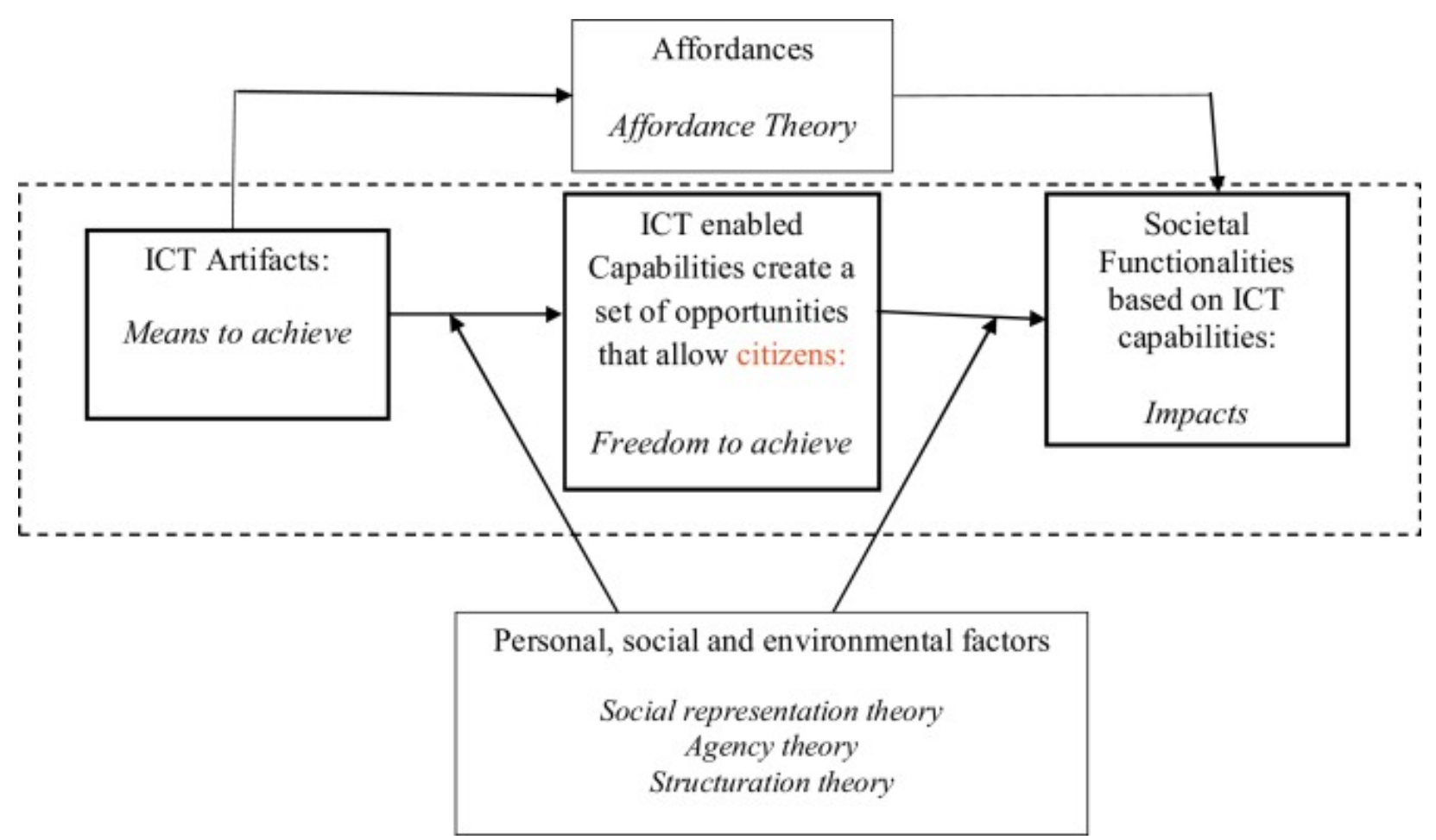

Fig. 2. A Theoretical Framework for ICT-based Socio-economic Impacts.

The theoretical framework relates the ICT artifacts, i.e., products and services like computers, telecommunications, mobile phones, etc., to the achievements made by the citizens of a country. According to the CA framework [42], [11], [36], personal, social, and environmental conversion factors shape the capabilities that can be obtained from ICT. According to CA, the capabilities represent vectors of potential functionalities available to an individual. The actual achievement of functionalities from the available capabilities is a personal choice subject to personal preferences and social factors.

The application of CA to ICT functionalities for development (or in other words, ICT impact on development) is more complex than a simple selection from existing capabilities and therefore requires further analysis and consideration. Fortunately, both IT and related literature provide several theories in this regard. In particular, the following theories provide further guidance: the agency theory [43], structuration theory [43], [44], affordance theory [45], and social representation theory [46]. What is implied from the CA framework is that functionalities are a simple subset of existing and defined capabilities may not be necessarily true. According to the human agency and agency theory, "humans are relatively free to enact technologies in multiple ways, and technology is implicated in social change at the discretion of human agents [47]. Giddens [43] defined agency as the 'capacity for action,' and as such only humans are empowered with this power of action. This observation again emphasizes the point that ICT impacts are not static or pre-defined; they are dynamic and evolving - thus the citizens' views are important. Furthermore, [43] Gidden's structuration theory (1984) provides key concepts relating individuals and society. Social structures and human agency represent mutual 
constitutive duality, and social phenomenon is not the product of any single one of them, but both of them combined. The structuration theory has been applied in IS research [44]; many of these studies have addressed the mutual effect of technology and social processes. In effect, societal impacts are generated by a complex interplay of technology, individuals, and social processes. Building on similar ideas, the affordance theory [45] puts forth the idea that human agencies and material agencies are imbricated in overlapping patterns. These agencies are the building blocks of routines or technologies. By imbricating the human and material agencies in different patterns, new routines and technologies can be developed. Thus, new IT impacts may be observed outside the existing and predefined capabilities.

Another theory, the social representation theory, provides a framework for the complex social phenomenon of the interplay between individuals and social structures. It was first articulated by Moscovici in the early 1960s [48] and has become one of the major theories in social psychology. We argue that ICT use in many countries, especially developing countries, fundamentally reshapes the interplay between individuals and their social structures to form new social representations related to socio-economic development. This is the core of the social representation theory. In fact, Sen [49] argued the capabilities from a social representation theory perspective, in which meaning making is a prerogative of the citizens. A social representation is the "collective elaboration of a social object by the community for the purpose of behaving and communicating" [48]. It can be viewed as "thoughts of movement" that are developed based on communications among members of a society [46]. Social representations are formed using two basic communicative mechanisms of anchoring and objectifying [50]. In brief, anchoring makes the unfamiliar familiar by comparing and interpreting its meaning to an earlier familiar representation. Objectifying makes the unknown known by transforming it to something concrete that an individual may have perceived, sensed, or touched.

The above concepts and theories can help explain the impact of ICT on socio-economic development. While we do not provide a detailed application of these theories and concepts due to the scope of the paper, they provide a plausible explanation of our findings.

\section{Methodology}

\subsection{Narrative research method}

There are two dominant approaches in information systems research: positivist and interpretive [51]. The "positivist" philosophy assumes that an objective reality exists independent of humans. A structure exists and an a-priori model can be built and tested with an appropriate set of constructs and an accurate set of instruments. In our research, while we do have some guiding theories and a framework, we do not have a precise structure for defining socioeconomic development and its constituents from a citizens' perspective. Therefore, the "interpretive" philosophy is more appropriate for our study as it postulates that reality and knowledge are social products and cannot be understood independent of the social actors. Furthermore, interpretivism underscores the importance of subjective meanings and sociopolitical processes in the elicitation of knowledge. 
Qualitative methods of research are generally associated, although not exclusively, with the interpretive approach. Major qualitative methods include case study research, ethnographic research, grounded theory research, phenomenological research, and narrative research [52]. While the "narrative" method has been used sparingly in the IS literature (e.g., [53], [54], [55], it was a natural choice when attempting to collect data from ordinary citizens. Narratives are collected stories from individuals (as well as from documents and group interactions) about individuals' lived and told experiences [52]. The basic idea behind the narrative research method is that all people can tell stories. Storytelling is a universal social activity that we are taught as children while learning to speak. Specifically, for the purpose of studying socio-economic development:

an especially appealing attribute of (narrative research) is the way in which it can display the assets of those usually considered to have none. A lack of academic learning does not preclude expertise in narrative knowing or skill in narrative expression [56].

A clear advantage of the narrative approach is that narrators from a variety of circumstances, including illiterate, highly literate, younger folks, and older people in urban and rural areas can become research participants. The collection and analysis of stories add a dimension missing in other methodologies. Participants' narratives are not only valuable for the information they provide but also allow us to see socio-economic development through the eyes of those whose lives are changed by it. The researcher's perspective can be enlarged or even changed by the interpretations of those at the grassroots of development. The significance of narrative is that,

its information comes complete with evaluations, and explanations and theories, with selectivities and silences, which are intrinsic to its representation of reality. (Narrative research), in all its rich wholeness, will illuminate conscious human activity in a way positivism never can. (PMG in Casey [57])

There are others who have advocated the use of the narratives in social research. Murray [58] explored the connection between narratives and social representations and finds a natural synergy between the two. Social representation is concerned with understanding everyday common sense and connects the individual with the social. In this sense, citizens' individual stories are helpful in developing the larger social picture. As Riessman [59] pointed out, "Studying narratives is... useful for what they reveal about social life; culture 'speaks itself' through an individual's story." Narrative research has also been found useful for studying the perceptions of various social groups. Because communication is a social activity, children are initiated into particular social identities as part of specific social communities with their own perspectives and ways of interpreting experience. The term "social dialect" [57] refers to commonalities of vocabulary, grammar, values, and beliefs that can be found in the transcribed narratives of members of the same social group. These commonalities constitute the elements of a "cultural framework of meaning" [56].

To receive the full benefits of narrative research, the researcher must allow participants to answer a broad question instead of responding to a fixed interview protocol. This permits the speakers to set their own agenda and respond in their own words, without interruptions from the researcher [56], [59], [60]. In this study, a brief overview of the research was followed by an 
open-ended question shown below, with the goal of providing the storytellers with flexibility and choice to narrate the story in a way that is most important or comfortable to them.

\section{I am studying the role of ICT in socio-economic development; please tell me the story of your life.}

We realize that many readers may not be familiar with narrative research. While the goal here is not to provide a detailed exposition to narrative research, the important steps are outlined. According to Riessman [59], there are five steps in conducting and analyzing narratives. The first is Attending. It is important to pay attention to how a storyteller makes sense of an experience, the context of the experience, and selectivity of the experience. The second step is Telling. A storyteller sequences and orders the events of the experience in a particular way. The narrative method allows for flexibility in how the story is communicated. While oral tradition is the most common, other expressions such as biography, story, novel, essay, or even a drawing can be used. The third step is Transcribing. This does not necessarily mean literal textual transcription but a way of keeping sequential record. A video-recording (or audio-recording) does even a better job than a literal transcription because it can preserve the contextual richness related to body language and interview environment. The fourth step is Analyzing. Analysis may employ qualitative techniques such as identification of codes and categories. Higher level categories may be developed by combining related codes, representing an increasing level of abstraction. The abstract categories are scaled up to develop broader level themes. The analysis of a narrative encompasses understanding of a statement within the background and context of the story teller. This emphasizes the need to focus on the whole story and not just the dissected parts of the story. Other aspects of analysis require attention to "selectivity" (what the narrator chooses to tell), "silence" (when the narrator chooses to keep quiet about some parts of their lives), "slippage" (contradiction within or between narratives), and "intertextuality" (comparing and contrasting different narratives). The final step is Reading. Listeners or readers may bring another layer of meaning to the experience and the identity of a storyteller. This means that our understanding of the narrative may be different from what the narrator wanted us to know.

\subsection{Research design}

The data were collected in Pakistan. There are several reasons for selecting Pakistan for this research. First, Pakistan has had several ICT successes and failures as ICT policies were developed, adopted, and implemented during the last several years. Second, Pakistan is the seventh largest populated country with over 170 million people and has the highest 1-year growth rate of ICT industry (147\%) in the world, followed by Bangladesh (135\%), and India $(97 \%)$ [61]. Third, a large portion of the population lacks access to basic ICT needs such as reliable electric power and infrastructure. The cost of traditional ICT infrastructure, devices, and services is significantly high, and therefore, the government has pushed deregulation policy while enabling legislation to facilitate wireless ICT access. As a result, the telecommunication subscriber base has climbed sharply reaching 137.7 million in 2014, from only about 0.3 million in 2000 and 34.5 million in 2006 [62]. Moreover, cellular teledensity has jumped to $76 \%$ from that of $22 \%$ in 2005-2006 [62]. Fourth, a large segment of the Pakistani society suffers from the lack of basic resources, illiteracy, and low income. Even if ICT access was made possible to this segment, it would still be challenging to sustain meaningful impact on their lives. Finally, 
Pakistan is experiencing an evolving regulatory framework with changes in ICT policies since the early 1990s [63], [64], [65]. Pakistan has continuously experimented with and adopted policies to increase ICT access and strived to create an enabling environment for the growth of the ICT sector. It is our expectation that lessons learned from Pakistan would be valuable for other developing countries experiencing similar ICT growth issues. Fig. 3 shows a map of Pakistan and the location of research sites.

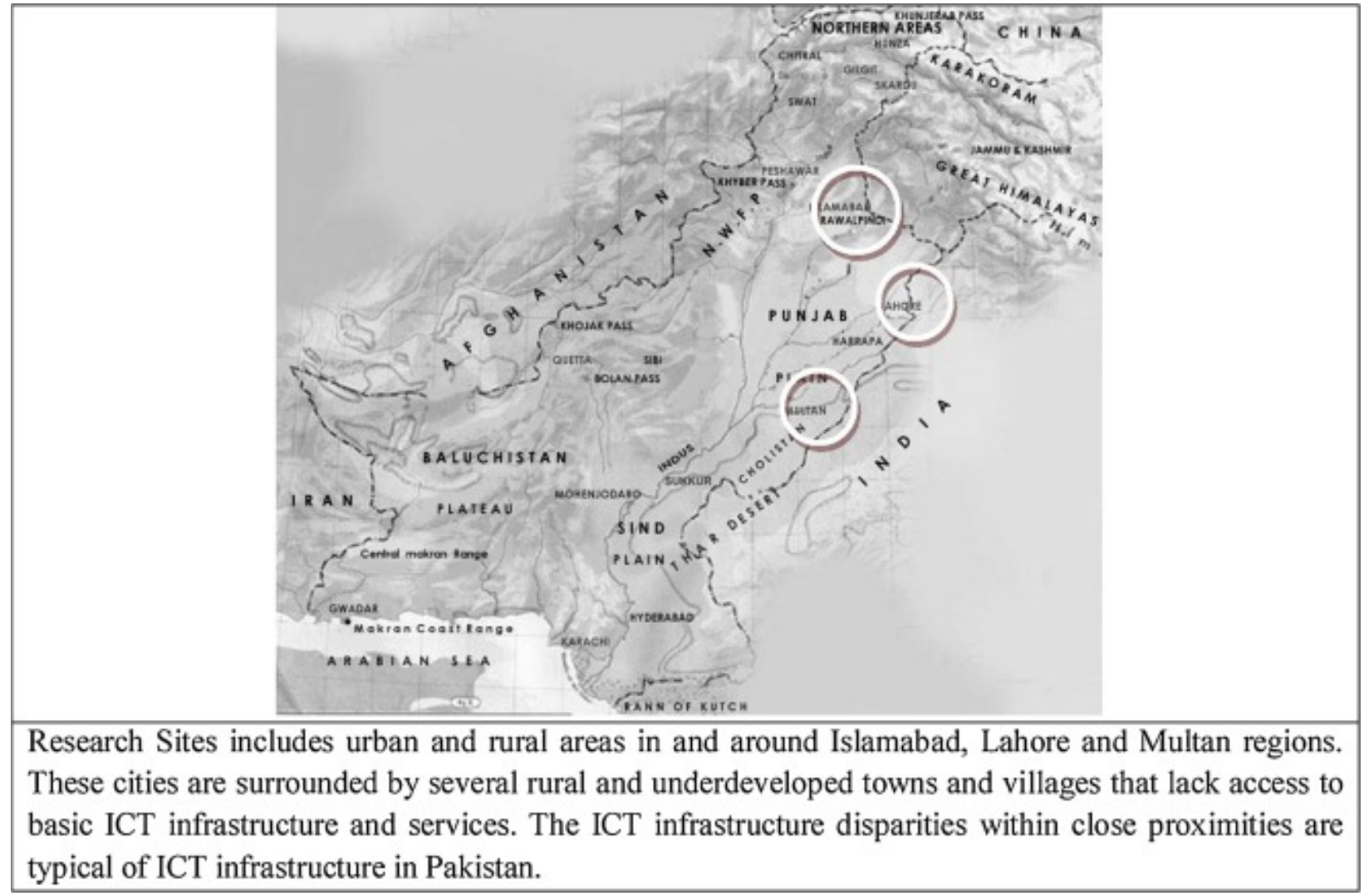

Fig. 3. Pakistan and Research Sites.

The selection of citizens is an important step in research design. Cresswell [52], Casey [56] and Reissman [59], emphasized a purposeful selection of research participants. The concept of theoretical sampling has been popularized in IS research, which requires qualitative researchers to carefully choose where to sample the next unit in a given situation [66]. The selection of various social groups of participants is crucial in getting the widest possible range of responses. Therefore, a set of four criteria, namely gender, domicile, income, and education was used to select the participants in this study. The actual selections were made through personal connections and referrals by others.

Gender plays an important role within the cultural and social environment in Pakistan. It usually defines how people think, act, and interact with others. Therefore, it is important to include both genders proportionally. Despite our best efforts, of the 35 research participants, only 9 were women. The low participation of women is indicative of the socio-cultural norms, which inhibit women from voicing their opinions and keep them within defined socio-cultural boundaries. Even though the number of women is low, the depth of the thought process and richness of their 
narratives were noteworthy. Casey [56] suggested including approximately six participants from each category, and therefore, this number is still satisfactory.

The government of Pakistan designates rural and urban areas throughout Pakistan and this list was used to categorize participants' residence as rural or urban and thereby ensure a fair representation. A proportional selection of participants was made on the basis of income (high, medium, and low). Individuals having an annual income within the nontaxable range were considered low income. Non-taxable range usually includes people below the national poverty line. In 2008, it was Pak Rupees 100,000 (approximately \$1300) [67]. Participants with annual earnings of Pak Rupees 500,000 (about \$10,000) are considered high income and are among the top 5\% of the population. Citizens in between these limits are categorized as medium income. The level of education allows us to capture the level of comfort in using technologies that rely on reading and writing (particularly in English). People with at least a bachelor's degree are considered highly educated, and those with no formal schooling are considered illiterate. Those between these limits are participants with medium level of education.

According to the narrative research method, no formal interview protocol was used to allow flexibility in the way citizens choose to present and sequence their stories. A brief overview of the research was followed by the open-ended question: "I am studying the role of ICT in socioeconomic development; please tell me the story of your life." Narratives were collected from 35 research participants in four languages: English, Urdu, Saraiki, and Punjabi (one of the coauthors is fluent in all four languages). Some interviews lasted as long as $8 \mathrm{~h}$. Theoretical sampling was used to ensure a representative involvement of participants from different socioeconomic and cultural backgrounds. Identification of codes and categories within the narratives was performed using the grounded theory method, which includes open coding and axial coding [52].

Table 2. Research Design.

\begin{tabular}{|c|c|c|c|c|c|c|c|c|}
\hline $\begin{array}{l}\text { Research } \\
\text { Participan } \\
\text { ts }\end{array}$ & $\begin{array}{l}\text { Data } \\
\text { Collection } \\
\text { Method }\end{array}$ & $\begin{array}{l}\text { Time/Space } \\
\text { per } \\
\text { participant }\end{array}$ & \multicolumn{5}{|c|}{$\begin{array}{l}\text { How were research participants } \\
\text { selected }\end{array}$} & $\begin{array}{c}\text { Data } \\
\text { Collection } \\
\text { Protocol }\end{array}$ \\
\hline \multirow{7}{*}{ Citizens } & \multirow{7}{*}{$\begin{array}{c}35 \\
\text { Interviews }\end{array}$} & \multirow{7}{*}{$\begin{array}{l}1 \text { to } 8 \\
\text { hours per } \\
\text { interview }\end{array}$} & \multicolumn{5}{|c|}{$\begin{array}{l}\text { - Gender (Men, Women) } \\
\text { - Domicile (Urban, Rural) } \\
\text { - Education (High, Medium, Low) } \\
\text { - Income (High, Medium, Low) }\end{array}$} & \multirow{8}{*}{$\begin{array}{l}\text { Unstructured } \\
\text { - Grand Tour } \\
\text { Question }\end{array}$} \\
\hline & & & \multicolumn{2}{|c|}{ Gender } & \multicolumn{3}{|c|}{ Income } & \\
\hline & & & Men & $\begin{array}{l}\text { Wo } \\
\text { men }\end{array}$ & High & $\begin{array}{c}\text { Mediu } \\
\mathrm{m}\end{array}$ & Low & \\
\hline & & & 26 & 9 & 4 & 13 & 18 & \\
\hline & & & \multicolumn{2}{|c|}{ Domicile } & \multicolumn{3}{|c|}{ Education } & \\
\hline & & & $\begin{array}{c}\text { Rur } \\
\text { al }\end{array}$ & Urban & $\begin{array}{c}\text { Hig } \\
\mathrm{h}\end{array}$ & $\begin{array}{c}\text { Mediu } \\
\mathrm{m}\end{array}$ & Low & \\
\hline & & & 19 & 16 & 7 & 12 & 16 & \\
\hline Citizens & $\begin{array}{l}\text { Two focus } \\
\text { groups of } 5 \\
\text { highly educated } \\
\text { and } 6 \text { illiterate } \\
\text { citizens from } \\
\text { urban and rural } \\
\text { area respectively }\end{array}$ & $\begin{array}{l}90 \text { Minutes } \\
\text { per focus } \\
\text { group }\end{array}$ & \multicolumn{5}{|c|}{$\begin{array}{l}\text { - Focus groups based on Education and } \\
\text { Domicile } \\
\text { - Representatives from urban area were } \\
\text { highly educated. } \\
\text { - Representatives from rural area were } \\
\text { illiterate. }\end{array}$} & \\
\hline
\end{tabular}


Additionally, two focus groups were employed to understand the collective sense-making of the role of ICT in citizens' lives. One focus group was conducted in Islamabad, a large metropolitan, and involved highly educated participants. The second focus group was conducted in a rural area and involved illiterate citizens. The interviews were recorded on video tape, except in two cases where video recording was not possible. The data collection was risky, expensive, and timeconsuming. Pilot studies were conducted 6 months prior to final data collection. The gap between these periods allowed for moments of pause and reflection. Table 2 provides details of the research design. Select backgrounds and narrative summaries are provided in Appendix A.

\section{Analysis and findings}

The analysis is based on the guidelines of narrative research. With consideration for selectivity, silence, slippage, reading, and intertextuality, codes and categories were identified using the NVIVO software. This process is called open coding Creswell, 2013. Higher level categories were developed by combining related codes, a process called axial coding. This represents an increasing level of abstraction. These abstract categories were scaled up to develop broader level themes that are referred to as impact dimensions of socio-economic development. The identification of these dimensions is a significant contribution to the literature on socio-economic development, and it enhances our understanding of the concept from the citizens' perspective. In terms of the theoretical framework depicted in Fig. 2, these dimensions refer to societal functionalities enabled by the IT artifacts and their capabilities, in both predicable and mysterious ways.

\subsection{Impact dimensions of socio-economic development}

From the qualitative analysis of narratives, 1229 codes were identified, which, through the process of hierarchical aggregation, were categorized into five dimensions. These dimensions are grounded in qualitative data and provide an understanding of what socio-economic development means to citizens. Table 3 provides details on code categories, keys terms and phrases, and the dimensions. Each dimension is described and discussed further.

Table 3. Dimensions and Code Categories of Socio-economic Development.

\begin{tabular}{|c|c|c|c|}
\hline \begin{tabular}{|l} 
Dimensions of \\
Socio-economic \\
Development
\end{tabular} & Categories of Codes & $\begin{array}{l}\text { Code } \\
\text { Frequency }\end{array}$ & Key terms and phrases \\
\hline Social Contact & $\begin{array}{l}\text { Staying in touch with family } \\
\text { and friends, develop new } \\
\text { friendships, replacement of } \\
\text { pen-pals to SMS buddies }\end{array}$ & $367(30 \%)$ & $\begin{array}{l}\text { "Now I can keep in touch with my family whenever and } \\
\text { wherever I go," "I don't cry anymore; I can speak with my } \\
\text { children as much as I want without worrying about the bill," "I } \\
\text { sometimes see my children [living abroad] on a webcam as } \\
\text { well," "the ability to stay in touch with family alone is the most } \\
\text { important blessing that comes with owning a cell phone," } \\
\text { "when I am on a business trip abroad, I can still see my 5- and } \\
\text { 2-year-old girls on webcam, and they can see me too; ICT } \\
\text { keeps us united even when we are physically apart," 'I } \\
\text { probably would not be pursuing higher education if I didn't } \\
\text { have a cell phone and my parents didn't feel that they can keep } \\
\text { in touch with me anytime they wanted." }\end{array}$ \\
\hline
\end{tabular}




\begin{tabular}{|c|c|c|c|}
\hline \begin{tabular}{|l|} 
Dimensions of \\
Socio-economic \\
Development
\end{tabular} & Categories of Codes & \begin{tabular}{|l} 
Code \\
Frequency
\end{tabular} & Key terms and phrases \\
\hline \begin{tabular}{|l|} 
Economic \\
Transformation
\end{tabular} & $\begin{array}{l}\text { Effective management of } \\
\text { current business, increased } \\
\text { business opportunities, new } \\
\text { business opportunities, status } \\
\text { of old business }\end{array}$ & $289(23 \%)$ & $\begin{array}{l}\text { "My costs of doing a business have gone down because I don't } \\
\text { need to rent a shop anymore," "My business has expanded } \\
\text { several folds since I started using a phone and email to keep in } \\
\text { touch with my suppliers," "I do more business and my } \\
\text { customers never have to leave their place to come see me. They } \\
\text { just call me and I am there for a service in a few minutes," "I } \\
\text { have just hired three employees to look after my current } \\
\text { business and I am now starting a new business," "I had a public } \\
\text { call office (PCO) in a village and made tons of money, but for } \\
\text { the last three years, I have shut it down and started a new } \\
\text { business; no one uses PCO anymore; everyone has a cell } \\
\text { phone." }\end{array}$ \\
\hline $\begin{array}{l}\text { Empowerment in } \\
\text { Life Domains }\end{array}$ & $\begin{array}{l}\text { Opportunities for education } \\
\text { and learning, opportunities } \\
\text { for healthcare, participation in } \\
\text { the political process, self- } \\
\text { fulfillment, self-efficacy, self- } \\
\text { empowerment, news and } \\
\text { media, entertainment }\end{array}$ & $254(21 \%)$ & $\begin{array}{l}\text { "I probably would not be pursuing higher education if I didn't } \\
\text { have a cell phone and my parents didn't feel that they can keep } \\
\text { in touch with me anytime they wanted," "I use online library to } \\
\text { find research papers to support my literature review," "I } \\
\text { frequently send SMS [short messaging service] to TV channels } \\
\text { that display my message on current affairs at the bottom of the } \\
\text { screen; I feel my SMS gives me voice and I can say things I } \\
\text { believe in," "I have not bought a newspaper in years; I get my } \\
\text { news on Internet and TV," "I love live coverage of political } \\
\text { issues; it gives me a sense of involvement and I feel I am } \\
\text { learning and participating." }\end{array}$ \\
\hline \begin{tabular}{|l} 
Cultural \\
Evolution
\end{tabular} & $\begin{array}{l}\text { Changes in social behavior, } \\
\text { westernization/globalization } \\
\text { of culture, family life, respect } \\
\text { for others, addiction of ICT } \\
\text { use, nuisance, pornography, } \\
\text { waste of time, unnecessary } \\
\text { expense, lack of attention, } \\
\text { lack of privacy }\end{array}$ & $126(10 \%)$ & $\begin{array}{l}\text { "I have seen a lot of girls and boys making out on phone and } \\
\text { even deciding on marrying without their parents' approval; this } \\
\text { is very bad," "People see icons of Western culture, try to adopt } \\
\text { their style and act like them too... this is a big threat to } \\
\text { indigenous culture and values," "I cannot concentrate on } \\
\text { anything because of I am always getting emails and SMS-- } \\
\text { even in the middle of the night," "I cannot go to a park or } \\
\text { anywhere else and have a quiet time; phones keep ringing } \\
\text { everywhere," "only time I get relaxed is when I shutdown my } \\
\text { computer and cell phone." }\end{array}$ \\
\hline $\begin{array}{l}\text { Personal Security } \\
\text { and Criminal Use }\end{array}$ & $\begin{array}{l}\text { Sense of security, peace of } \\
\text { mind, harassment, sexual } \\
\text { misconduct, fear of being } \\
\text { robbed, stealing, online fraud, } \\
\text { ICT use for criminal activities }\end{array}$ & $193(16 \%)$ & $\begin{array}{l}\text { "Even if I don't have to call anyone, my cell phone gives me a } \\
\text { sense of security that I am not alone," "cell phones give peace } \\
\text { of mind that you can call anyone if you are in trouble," "I was } \\
\text { once robbed; all this other dude wanted was my cell phone," "I } \\
\text { know it is wrong to steal money to pay for my cell phone bill } \\
\text { but I cannot help it," "a lot of online "scamsters' would try to } \\
\text { rip you off if they found out that you were an easy victim." }\end{array}$ \\
\hline Total codes & & $1229(100 \%)$ & \\
\hline
\end{tabular}

\subsection{Social contact (I don't cry anymore)}

ICT provides both artifacts and capabilities for connection and communication with others. However, our analysis unfolds how these capabilities transcend into social contact. Simply said, social contact is the ability of a person to stay in touch with family and friends. While social contact may be defined in a number of ways, it is defined herein in terms of what research participants used, i.e., staying in touch with family and friends, developing new friendships, and 
replacement of pen-pals with SMS buddies. The highest frequency of codes (367 or 30\%) related to this dimension shows that social contact was very important for the research participants.

An educated urban woman, whose children live abroad, narrated an emotional personal story. She had not seen one of her sons in several years. She used to wait for the weekends so that her children can call her. The international call was expensive, and she could only speak for a few minutes. She used to cry during the week and anxiously counted days until the weekend. She said,

I used to cry too much, and my husband always told me that our children abroad are studying and doing very well. They take care of us; they call us and visit us frequently. The youngest one has not visited me in years. He loves me very much, but his work visa application is in progress and he cannot come to see me until it is complete. I miss him too much, and when I think about him, my eyes start shedding tears. I cannot stop missing him.

She did not believe when she heard of special international calling packages that allowed her to make international calls at local toll rates. She explained,

I don't cry anymore; I can speak with my children as much as I want without worrying about the bill. I call them almost every morning. I can actually call them anytime I want, but I understand that they might be busy. So, I only call them in the morning, which is evening for them.

An executive of a software development house who frequently travels internationally narrated an emotional and powerful personal story. He travels for weeks leaving his two little girls, wife, and old parents back home. His ability to stay connected with his family is an important aspect of his ICT use. He explained,

When I am on a business trip abroad, I can still see my 5- and 2-year-old girls on webcam, and they can see me too; my mother does not feel that I am away because she can still see me and speak with me every night before she goes to her bed. ICT keep us united even when we are physically apart.

The use of ICT for staying connected is not limited to educated participants in urban areas alone. From illiterate farmers in rural areas to blue-collar workers in Multan and Islamabad, the ability to stay in touch with family is the most important aspect of everyday ICT use. However, for illiterate people, the scope of devices that they can use usually remains limited to cell phones. Cell phones are readily available, easy to carry, and cheap (cell phone is available for under $\$ 20$ - 1500 rupees - and the cost of ownership is as low as a couple of dollars each month). It makes these devices ideal for use by people with little or no education. Furthermore, the use of cell phone is not limited to voice communication alone. The use of Short Messaging Service (SMS) and Multimedia Messaging Service (MMS, which allows transmission of files, photos, and videos) was quite common among illiterate research participants. 
An illiterate research participant, who is a honey farmer, travels great distances to find flowers. His job requires him to stay away from his family for months. His cell phone allows him to keep in touch with his wife and parents. He said,

I speak with my wife for hours in the night when the service is free. If my mother needs to speak with me, she can always find me. I cannot read, but a friend of mine has shown me how to take a photo on my cell phone and send it to someone else. I do send photos of new places to my family that I discover in search of flowers for bees

The concept of friendship was very important to several participants. The stories of meeting someone at a bus stop or elsewhere and then staying in touch with them were credited to ICT. A young participant said,

I love making friendships. I used to have 20 pen-pals when I was in school. I have not written a single letter in three years now, and I have more friends now. When I SMS a joke, or forward an email, sometimes there could be as many as 300 receipts. I have a Facebook page, and my family and friends in other cities and abroad know whatever goes on in my life at work and home. I just love it all, and I cannot imagine how anyone else can live without these things.

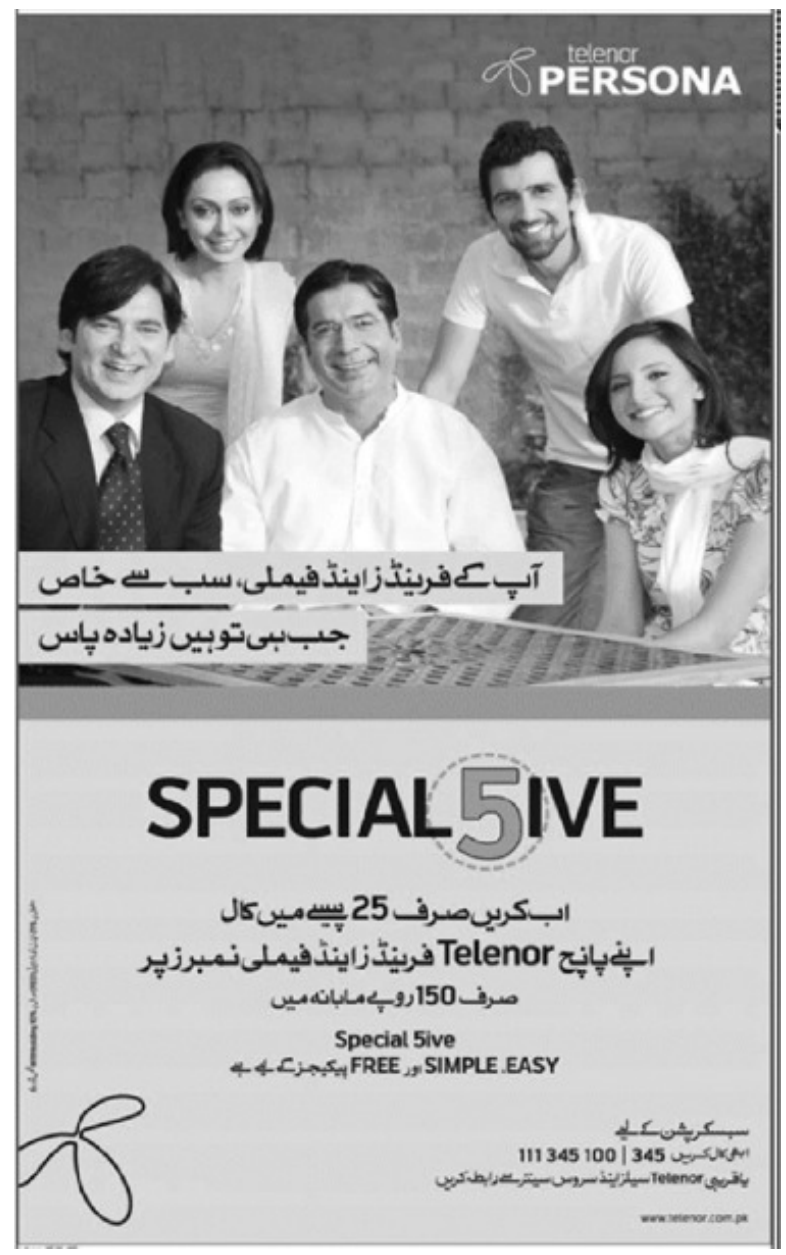

Fig. 4. Newspaper Advertisement of a Cellular Service Provider Offering. 
Evidence from narrative research can be corroborated from other sources. Further evidence of the importance of this dimension comes from a review of ICT service providers' advertisements in national newspapers. These advertisements offer special calling rates and ease of use features for staying in touch with friends and family. Fig. 4 shows one such advertisement.

\subsection{Economic transformation (I can earn as much as I want)}

Economic transformation would not be normally considered an ICT artifact or a direct capability of the technology. However, it is one area where ICT has provided many life-changing opportunities to citizens. Economic transformation refers not only to economic productivity but also to increase in market size of existing businesses, new business opportunities, and demise of some old businesses. This concept emerged as an important theme across participants from different backgrounds; it had 289 or $23 \%$ of the codes associated with it. Economic development due to ICT has been observed in other developing countries, such as Tunisia [68] and Poland [69].

The use of ICT (such as cellular phones, Internet, television) to support economic transformation was unique and interesting. One participant, who hauls loads on his donkey-driven cart from warehouses to furniture showrooms when someone makes a purchase, narrated the following:

The owner of the showroom would go and peek out of his place to see if someone with a donkey cart was there. There are a lot of people searching for work around the furniture market. I get paid only when a customer makes a purchase at a showroom, and I am available to bring furniture from the warehouse. I am not too lucky and most of the time others who are standing nearby will grab the job before I even know about it.

Then he got a cell phone. He cannot read, even numbers (so he visually matches patterns for a number on a piece of paper to the dial pad of his phone). However, he got some help, which changed the dynamics of how he gets a job at the furniture market. He explained,

Someone helped me with setting up the phone for distinctive ring tones. Showroom owners give me a missed call, and I can recognize who needs my help by a specific ring tone setup for a particular showroom owner. Now, I can work as much as I want.

This innovative way of using cell phones to manage small businesses is not uncommon. Another illiterate participant who runs five-passenger vans for public transport said the following:

I have been in public transport business for about ten years. There are several other people who are in the same business. I cannot afford to buy new vans, and the older vans sometimes breakdown in middle of transporting customer. The fierce competition and low profit margins affect customer service. When a van breaks down, there is not much that the driver [his employee] can do except to help passengers get a seat on one of my competitors' vans. That makes me lose all the fare money my driver had collected. I am mechanic myself, but since I do not even know what happened to the van, the driver would have to get it fixed from someone else. That was a big expense. On the top of 
everything else, my van is not making me money until it is fixed and who knew how much time it might take before it gets back to business.

Since he got a cell phone for himself and his employees, his business runs relatively smoothly, and he has raised the level of customer service. He said,

I can keep in touch with my employees and know exactly where they are when a van breaks down. I can go and fix it myself. My employees do not have to run here and there to find another mechanic. To better serve my customers, I can dispatch a replacement van right away. It is a win-win situation for me, my employees, and my customers.

In several cases, ICT proved helpful in developing new business ideas as well. One participant was making a pulley system for a machine that could be used in construction or agriculture business to fetch loads or water. He explained how a TV program about making mechanical systems inspired him to make the pulley system. He shared the news that he has already found a customer who wants him to deliver this machine as soon as possible.

ICT growth has played an important role in changing the nature of competition. Those with knowledge to use computers and Internet have discovered new products and markets to sustain and transform their business. An educated participant who owns a small mechanical parts manufacturing facility in a small urban area shared his success stories. His father opened a mechanical workshop to fix and retool mechanical parts of tractors several years ago. The agriculture-based economy of the region meant a thriving mechanical repairs business in the 1980s and 1990s. However, the competition has increased, and it is difficult to make a reasonable living within the existing business. He said,

My father was the first person who opened up a mechanical workshop in this town. We did a lot of good business. We had to hire a lot of employees to keep up with the amount of work. These "boys" would learn how to use machines here, and a few weeks later, they would open up their own shop next door. Let me give you an example. We were the first ones to bring a diesel-testing laboratory in the town. Now there are many other diesel-testing labs that you can get a job done for 300 rupees today [in 2009] for which we used to charge 600 rupees in 1995.

Therefore, they decided to start a mechanical parts manufacturing business in 2002. They did not want to hire employees for the fear that the employees will open up same or similar business independently. They kept the manufacturing knowledge to their own family members. The demand for their parts grew steadily between 2003 and 2007. To keep up with the demand, he and his family decide to explore options to automate their manufacturing business. In late 2007, he imported a used machine, which could be used to automate the manufacturing process. However, the machine had missing parts and was not in operational condition.

We spent a substantial amount of money to buy this old machine... about 300,000 rupees. That's a lot of money for one piece of equipment considering you can open up two manual mechanical workshops for that much money. 
He used the Internet to find a manual for this machine, made and fixed some parts, and brought the machine to operational condition. The variation in production process has gone down $(0.0001 \%$ quality rejection rate), and demand has increased significantly ( $800 \%$ in 1 year). Now, he continuously uses Internet, email, and cell phone to stay in touch with his clients in different countries.

An illiterate entrepreneur woman shared her stories of success. She has a small cloth sale business in nearby towns. She travels as far away as 300 miles to buy cloth at wholesale prices and sells at profit to villagers who cannot travel. Her business has grown significantly since she got a cell phone because her customers can call and tell her what they want. She can now accept special orders, and her customers are very happy. She has expanded her business to farther villages because of her ability to stay in touch with her customers, understand market needs, and serve accordingly.

Several business owners are discovering that they can run their business more effectively and cut down on expenses by using ICT. For example, a plumber explained that previously he had to rent a shop just to make sure his customers can find him. With his cell phone, his business card bears his business name and cell phone number alone. He said he has more satisfied customers because they do not have to come to his place to find him.

My customers just call me on the phone and I can be at their place in no time. It saves me and my customers a great deal of time. I am more accessible, and I make more money than I used to when I used to rent a shop. I don't have to pay rent anymore, and I can save on my business expenses.

In some situations, ICTs have caused the demise of some types of businesses. As these businesses shut down, some have moved to explore other economic opportunities. For example, a research participant who owned and operated a public call office (PCO) experienced a thriving business in the 1990s and early 2000s. He narrated his story as follows:

I opened up a PCO in this town in 1992. My PCO's phone was the only phone in town and nearby villages where you could go and call someone in another city or country emergencies. The calls were expensive, but profit margin was great. I did very well for several years. Then, around 2003 and 2004, my business started to decline because cheap and easily available cell phones became affordable for my customers. I struggled for a couple of years, but in 2007 I gave up. For one week, I did not get a single customer in my PCO to make a call. I knew that was it for me in this business.

Now he operates a motorbike rental business. This story resonates with demise of several service sector jobs and businesses. Thus, ICT growth is also transforming the nature of business.

\subsection{Empowerment in life domains (I can do more things on my own)}

The "Empowerment in Life Domains" dimension was derived from 254 codes, representing 21\% of all codes. This dimension would be difficult to imagine based solely on the technology or its capabilities; rather, it is how it is employed by citizens in daily use in different domains that 
makes its true potential emerge. It is a comprehensive dimension comprising four major subdimensions: (1) education and learning, (2) healthcare, (3) political process and role of media, and (4) entertainment. Although we list them as subdimensions representing different aspects of empowerment in life, an argument can be made to list them as separate independent dimensions and may be the subject of future refinement. As background, the use of ICT for educational and learning opportunities has been wide spread. From access to free educational content at several universities to ICT use in traditional education, this trend can be clearly observed. The use of ICT is significant in rural healthcare where patients can call doctors and get advice for minor ailments. Awareness and understanding of the social and political issues have been brought about from the use of ICT such as special interest televisions on current affairs and social issue, Internet blogs, online message boards, SMS, and cell phones. Recently, Rahim et al. [70] reported improvements in education and socio-economic benefits of ICT among youth in rural and remote areas of Pakistan, and Skryabin et al. [71] evaluated how ICT development level and usage influence student achievement in reading, mathematics, and science.

The Virtual University of Pakistan and Allama Iqbal Open University have a wide student base throughout Pakistan and employ ICT such as TV, Internet, radio, and SMS to deliver educational content. Lectures and most educational materials are freely available. However, ICT use is limited in traditional institutions where research and teaching material are rarely available on university websites. ICTs have created an interesting situation where some students can pursue their education because their parents can now keep in touch with them. One young participant who was pursuing graduate-level education in Islamabad shared interesting insights about educational opportunities for young girls. Many students, especially girls, are not allowed to go to universities far away from their home towns. This participant excelled in her B.Sc. in 2005 and wanted to pursue M.Sc. in Microbiology. She said,

You know, not many universities in Pakistan have a good Microbiology program. I wanted to do my M.Sc. at Quaid-e-Azam University in Islamabad. That is one of the best programs around. But my parents would not allow me to go to a university, which is like 800 kilometers from my home... I wasted a year and could not start my graduate studies right after my B.Sc.

Her parents were concerned for her safety in a city 500 miles away. Cellular phones were becoming popular, and things changed for her when they got her a cell phone and found out that they could always stay in touch with her. She said,

Even though I started my M.Sc. one year later, I am glad I got this opportunity. My parents are very open minded, but they still feared for my safety... I probably would not be pursuing higher education if I didn't have a cell phone and my parents didn't feel that they can keep in touch with me anytime they wanted.

She accesses a large online library that helps her in research and access to latest publications in her areas of interest. She was also aware of several others who experienced the same struggle for their education in their families. 
The role of ICT in healthcare is important in developing countries. Pakistan, like other developing countries, suffers from shortage of qualified health professionals. The shortage is even severe in rural areas where natural hazards such as snake bites and hygiene-related ailments are common. A medical doctor shared a number of stories where villagers could get his advice for minor ailments on a quick phone call.

The importance of ICT became apparent during the October 2005 earthquake. Thousands of people died in that earthquake, and wired telephony systems were severely affected. Mobile cellular units were established in the affected areas, and medical camps were setup. However, there were not enough doctors. A participant who volunteered for the relief team said,

I was among the first responders. The biggest problem was to give medical care to the injured. There was only one doctor and thousands of injured people. An internet service provider setup satellite links to doctors in Europe and America who volunteered to assist with the diagnosis and prescriptions for the injured people. Two X-ray specialists ran X-rays for this camp where I was volunteering. I scanned X-rays and emailed those to volunteer doctors abroad. They diagnosed what needed to be done with detailed instructions so people with minimal medical training can run those procedures. We saved hundreds of lives in those few days.

ICTs have played a role in creating political awareness and opportunities for political participation. The special interest TV channels, e.g., news and current affairs channels, encourage viewers to send their opinions on SMS. The SMS messages scroll at the bottom of the screen. Most channels charge significant amount for receiving such messages. Although such services allow viewers to express their mind, it is a source of additional revenue for TV channels and the cellular service providers. A participant described his experience,

I love the live coverage of political issues; it gives me a sense of involvement, and I feel I am learning and participating... I frequently send SMS to TV channels that display my messages on current affairs at the bottom of the screen; I feel my SMS gives me voice and I can say things I believe in. I was extremely happy when I saw my message scrolling sideways at the bottom of my TV the first time. I paid 10 rupees for that message, but I was very excited to see that others can see what I have to say. I feel as if my voice is heard. I send these messages specially when there is a political debate or a crisis is going on. Initially there used to be few messages, but these days a lot of people send messages.

Politicians used SMS heavily to stay in touch with their constituents, especially during the campaigns for elections in 2008. A participant gave his account of excitement when he got an SMS from his favorite candidate. He said he was going to vote for this candidate anyway, but the SMS made him feel closer.

ICTs have changed how citizens get news. In addition to news on TV, several providers offer free SMS for breaking news. A number of online news websites are available. A participant narrated, 
I have not bought a newspaper in years. I get my news on internet and TV... I spend quite a bit of time online every day. Sometimes I watch cricket matches, and sometimes I even watch movies.

ICTs have increased opportunities for entertainment. The use of Internet-based entertainment content is limited to those who can afford to buy a computer and pay for Internet connection. In some cases, availability of Internet in the workplace and universities has created opportunities to download music, movies, and play games. This is also an additional source of revenue for service providers. Cellular service providers have subscription-based services and pay-as-youuse services for accessing musical ring tones, music libraries, religious music, movies clips, SMS, multiplayer games, live games commentary (mostly cricket), and on-demand content. A participant described his experiences:

I spend about 300-400 rupees [75\% of his monthly phone bill] every month on ringtones and music alone. I always use this facility for live commentary when Pakistani team is playing international cricket matches and I am unable to watch the game on TV. My phone does not have video capability and that's why I cannot use MMS services, but I am saving money to buy a more expensive phone which has more features. Some of my friends have those phones, and they can even watch funny video clips and movie clips.

Another participant at a university described the use of Internet for watching soap opera:

My work schedule does not allow me to watch my favorite episodes of TV dramas [soap opera]. Someone told me about a website, which has episodes of all the programs I wanted to see. Now whenever I get a break, I just go online and watch the programs I want to. This is a wonderful facility. That's the extent of what I do online though.

It is evident from this analysis and discussion of the narratives that ICT has empowered the citizens in many areas and improved their quality of life, thus contributing to their socioeconomic development.

\subsection{Cultural evolution (this is a big threat to indigenous culture)}

This is probably one of the most visible effects of ICT in developing countries, especially the Muslim world. A priori it was unexpected as it does not relate directly to the technology or its capabilities. This dimension was derived from the categories of codes that represent changes in social behavior, westernization/globalization of culture, family life, addiction of ICT use, pornography, nuisance, waste of time, unnecessary expense, and lack of attention. There were 126 codes $(10 \%)$ representing this dimension. Frequent references to cultural evolution were found in the narratives.

Although efforts for localizing and "aligning" technologies to local customs and traditions can be observed, ICT-based cultural evolution is inevitable. For some, these are the signs of progress, yet others consider it a threat to the indigenous culture, traditions, and customs. Situations where ICT were considered to cause a cultural evolution included issues such as (1) gender segregation, (2) sexual conduct, (3) respect for parents and elderly, and (4) westernization of several 
institutions. Some of these developments are at odds with local customs, and as such, some participants portrayed them negatively.

Some of the situations where ICTs were regarded a threat to local customs were representative of the socio-cultural norms of Pakistan. Gender segregation is regarded a cultural value and a symbol of respect for genders. Intermingling of genders is considered a sign of westernization. For example, a woman in rural area said,

I have seen a lot of girls and boys making out on phone and even deciding on marrying without their parents' approval; this is very bad. It was unthinkable to marry without parents' blessings. Marriage used to be a mystery in several respects for both girls and boys until the day they would get married. Sometimes the bride and the groom would meet for the first time [as in some arranged marriages] and lived happily ever after. Sometimes even when they knew each other in the case of family marriage, "silence" between the two was considered polite and a show of mutual respect for each other. Things are changing now. It is good that bride and groom understand each other before marrying, but I am just surprised on the amount of time girls and boys can spend on phone before parents give them blessings.

She admits that cell phones are very helpful in several aspects but does not want young girls and boys to be carrying phones around just to waste time in "useless" talk. She sees a major transformation in the social structure in rural areas where parents are losing control over children in young age because of cell phones.

Intermingling of genders is not considered inappropriate in the developed world. It is common to expect boys and girls to have intimate relationships without parents' consent and approval. Thus, ICT may bring about cultural evolution that is not approved by many citizens. ICT growth has increased access to what was considered "outside culture" by many participants. From comments on TV programs to Internet-based content, citizens showed concern for the impacts of westernization and foreign culture on the upbringing of their children.

The religious values and cultural traditions prohibit people from indulging in behaviors that are considered "sexually inappropriate". Access to pornographic material has traditionally been limited. However, with access to the Internet and MMS on mobile phones, it is far easier to access such material discretely. A participant who runs an Internet café shared his observations of young boys and girls:

I mind my own business, but at the end of the day, the server generates reports of most visited websites and pages. Pornographic content is at the top and free email services such as Hotmail, Yahoo and Gmail are grouped closely in the second place... Access to pornographic material has never been this easy. I see this as a major cultural shift, which is troubling. The internet has a lot of benefits for everyone, but we need to distinguish between good, bad, and ugly.

The lack of privacy and nuisance because of cell phones, TV, Internet, and computers was also considered against the cultural values that emphasize politeness and respect for others. Phrases 
such as "I cannot go to a park or anywhere else and have a quiet time; phones keep ringing everywhere," "only time I relax is when I shut down my computer and cell phone," and "I cannot concentrate on anything because I am always getting emails and SMS - even in the middle of the night; I don't want to be left out of the loop either" provide strong evidence that ICT growth is beginning to affect cultural values.

Family values are considered important in Pakistan. From giving up ones' own comforts for the future of children to taking care of the elderly are cherished values. However, ICT growth has created situations for some participants where they have to choose between economic opportunity and taking care of families. For example, a participant in a rural area earned the reputation of an excellent project manager at her workplace. Because of the problems in IT administration, she was chosen to take greater responsibility:

My boss did not give me a choice and wanted me to head the IT department. I told him that I didn't know a thing about computers, but he said I could learn these things. I got a big raise too... I enjoy this job because I have learned a lot here, but it has turned my family life upside-down and I cannot take care of my family and children as much as I used to do before... I feel bad that I cannot fulfill my responsibilities of taking care of my children in the same way that my mother did for my siblings and myself.

She carries her phone even when she is cooking food just in case she is needed during network and IT services disruptions.

In addition to positive aspects of ICT growth, the narratives frequently described ways ICT went against indigenous values. For example, ICT was cited as a reason for unnecessary expense, wasting time, and lack of attention in contrast to a culture of savings for the rainy day, valuing time, and showing politeness.

\subsection{Personal security and criminal use (I feel secure, but criminals also have more options)}

This dimension is an unanticipated effect of the technology and its capabilities and, to some extent, represents its dark side. It is a two-faceted impact and reflects two sides of the same coin. Although some aspects of ICT have provided more security and safety to individuals, it has also provided more options for perpetrating crime. This dimension is derived from categories of codes that represent sense of security; peace of mind; and, in some cases, fear of being robbed, harassment, sexual misconduct, stealing, online fraud, and ICT use for criminal activities. These constituted 193 codes or $16 \%$ of the total. The notion of the role of ICT for personal security came from narratives showing the ability to stay connected at all times with the use of a cell phone. The notion of criminal use emerged from stories of stealing money to pay for phone bill, fear of online scams, and preying upon unsuspecting victims.

In the developed world, once the police is notified, there is an expectation of security, safety, and protection for the person reporting the problem. This assumption might not hold true in several developing countries where police departments and law enforcement agencies have a reputation of being corrupt institutions. Traditionally, the role of police and law enforcement in society is portrayed negatively. Some of this is rooted in the colonial system where police was used as a 
tool to protect the interests of the government. Therefore, dependence on friends and family in the event of a problem or emergency is more common. In this regard, ICT provide a way of staying in touch with family and friends who can be trusted in emergencies.

From a personal safety perspective, women are considered vulnerable, especially when alone. It is normal to see women accompanied by a family member as a safety mechanism. Sometimes, even a small child accompanying a woman can counter the safety issue. Cellular phones can be carried around easily and used discretely. A woman expressed these feelings:

I have never stepped out of my house alone. I will always have someone with me... maybe even a toddler. A companion is an assurance that someone is with me to take care of me if I find myself in an odd situation. Since I got this cell phone, I know I can call my family members anytime. Now I feel OK to go out alone for shopping and to visit family members nearby. It is like someone is with me all the time. It's great to have a phone, particularly in an emergency. If something were to happen to me, my family will immediately know that I need help.

In a previous section, the narrative of a student was also evidence that even in "liberal" and "open-minded" families, cell phones are considered an important safety mechanism. However, a participant highlighted another aspect of personal security. This aspect involved being victim of the breach of personal security. He said,

I was once robbed; this dude wanted to snatch my cell phone... I know a few other people who were robbed for their phones. Even though regular cell phones are cheap, they can be sold for quick cash.

Similar parts of narratives were coded as "fear of being robbed," but the frequency of this category of codes was relatively low. Moreover, Pakistan Telecommunication Authority has activated a system where stolen and robbed phones can be permanently disabled when reported.

There are some criminal behaviors that might be considered universally inappropriate and unacceptable. Consider the narrative of a young barber who works at his father's shop. His daily pocket allowance is Rs. 20, but his daily cell phone expense is Rs. 500. He calls prostitutes and spends hours in discussions that may be described as erotic. For his addiction, he steals money from the cash drawer.

I know it is wrong to steal money to pay for my cell phone bill, but I cannot help it... my father sometimes suspects that I am stealing money from the drawer, but I don't leave a clue. I am quite expert at it now... I feel sad when I steal money, but then my desires to speak with woman takes me over and I cannot control myself... I just can't overcome my addiction of speaking with women who I don't really know... my father wants me to get married, but I have a lot of aspirations. I want to be famous and rich and have a good life... The cell phone makes me live a life of fantasy, and I feel that I am important because some women need me. I know it is not good, but I cannot help it and don't know how to stop it. 
ICTs have the ability to create a world of fantasy where people can forget about the realities of life or think about morality and legality of ICT use. There were more stories of online fraud and the use of ICT for criminal activities. An educated old woman described,
My bank has provided me an online ID and password for my account... I have internet access, and I use email to communicate with my siblings in other cities and countries... but I never log into my account online. I still do my financial transaction the old- fashioned way with a 'passbook' [a small diary that is used to record banking transaction for customer's own record] and checks. I have read about people whose accounts were wiped clean by criminal people... I just don't want to take chances.

The "Cyber Law Ordinance" that took effect in December 2007 was the result of using emails to lure Daniel Pearl of Wall Street Journal into a trap. Later, a video of his beheading was posted online. The criminals were apprehended after their IP address was traced. However, it was too late for Mr. Pearl. Currently, National Response Center for Cyber Crimes at the Federal Investigation Authority is responsible for tracking, apprehending, and prosecuting crimes including financial crimes that involve the use of ICT.

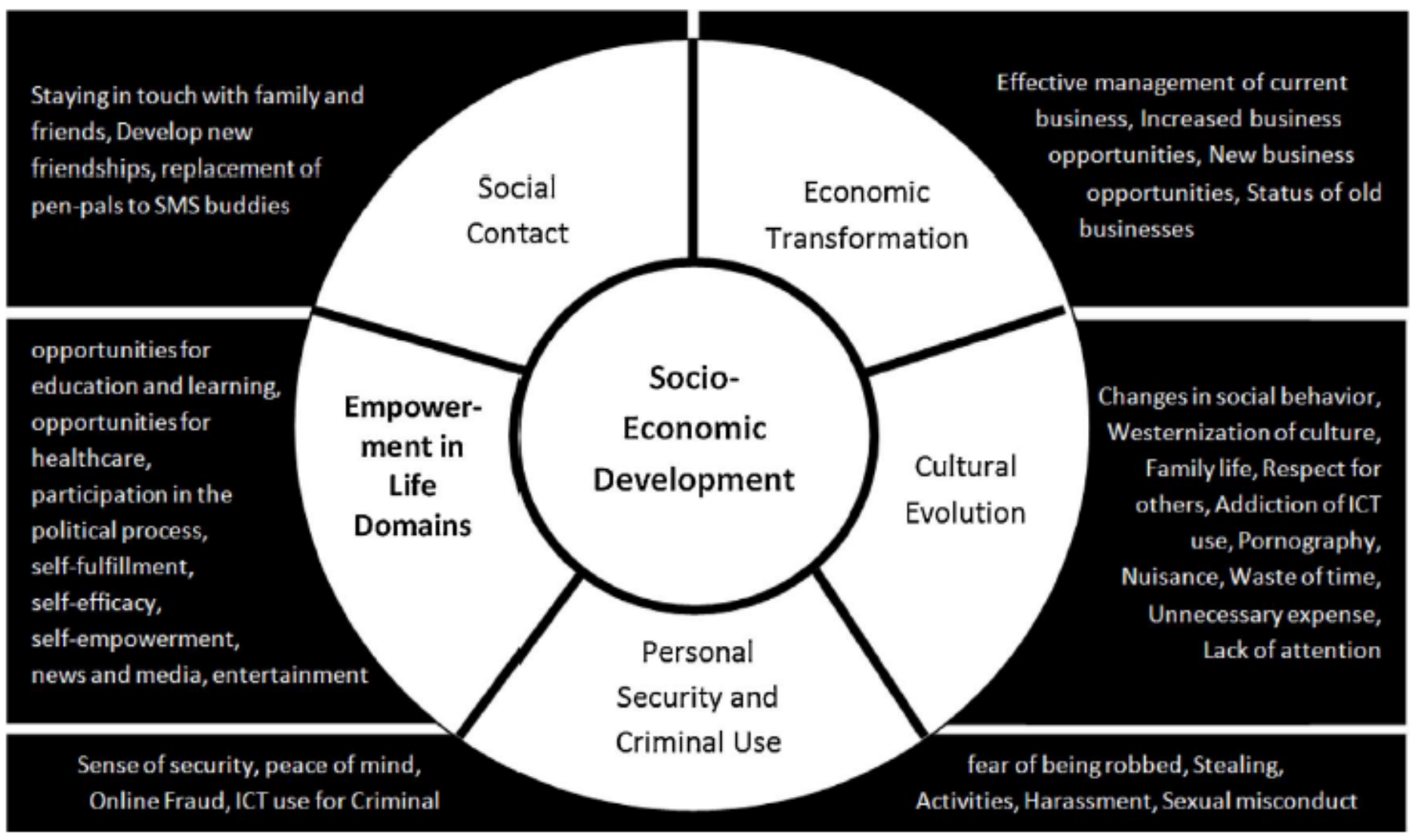

Fig. 5. A Model of ICT Impact on Socio-economic Development.

\section{Discussion}




\subsection{Theoretical model of ICT impact on socio-economic development}

A diagrammatic representation of the impact dimensions and themes identified by scaling up of the codes is shown in Fig. 5. This hierarchical model represents socio-economic development as the central theme and depicts the impact dimensions and the various categories of codes.

Much of the discussion has already been provided in the previous sections, and we do not wish to rehash it because of space limitations. Instead, to highlight the model's various strengths and realism, it is instructive to examine the model in comparison with the theoretical model proposed by Madon [31]. The Madon model, being the primary model in the context of ICT for socioeconomic development, provides an effective benchmark for the following additional discussion. We also point to various theories in play that were described in our theory development section.

\subsubsection{Economic growth vs. economic transformation}

The notion of economic growth is derived from application of the Internet for economic productivity. However, terms such as economic growth and economic productivity are not always positive influences. The positive impacts of ICT were found true in the narratives of present research; however, citizens also recognized the negative impact of ICT, which were missing in Madon's conceptualization. Although not intended as negative impacts of ICT capabilities, the agency theory and structuration theory [43], [44], would suggest that human beings would discover new meanings and consequences of technology. Economic productivity does not sufficiently address the demise of old business models and regimes with the introduction of ICT. Our research extends previous notions of economic growth and productivity with the use of a more encompassing term: "economic transformation." Economic transformation addresses the impact of ICT on businesses and individuals whether it is positive or negative. Additionally, it addresses poverty alleviation, as reinforcement of Madon's model, which captured it as part of social wellbeing.

\subsubsection{Social wellbeing and political wellbeing vs. empowerment}

Madon derived the social wellbeing dimension from Internet applications in education, health, poverty alleviation, and empowerment. The political wellbeing dimension was derived from application of Internet for democracy. Our "empowerment in life domains" dimension is more encompassing and reflects opportunities available to individuals in various realms of life. The qualitative evidence from the narratives showed many examples of ICT application in education, healthcare, political speech, democracy, and entertainment. Many of the applications were unique, which support the notion of affordances and that human and material agencies can be imbricated in different and new patterns [45].

\subsubsection{Physical environment and sustainable development}

This is an example of a theoretical capability that may not be realized in a particular social context. Madon theorized the role of the Internet and ICT in sustainable development and environmental protection. This issue was not sensed by the citizens of Pakistan in our study. Analysis of the citizens' narratives did not produce evidence of sustainable development as a 
concern. In Pakistan, ICT growth has been rather fast, and the fast pace of development has resulted in continuous introduction of new ICT products and services, without regard for environment or sustainability. As shown in our theoretical framework of Fig. 2 and by other authors [42], [11], [36], capabilities may not convert automatically to realized functionalities; the effect is influenced by personal and social factors.

\subsubsection{Personal security and criminal use and cultural evolution}

These were new impact dimensions that were not included in Madon's conceptualization. Once again, the agency theory and structuration theory [43], [44] as well as affordance theory [45] help explain these rather unanticipated findings. Once ICT is used by the citizens, they can discover new and novel uses and impacts of technology. The social context of Pakistan is also an important factor in this revelation. In many developing countries, the fear of being robbed and not having police to help pose a real threat to the citizens. Cultural evolution is another impact felt by the citizens of Pakistan and is a matter of concern for parents and policy makers. In our belief, these two dimensions are unique to people in developing countries and have not been discussed in the literature.

\subsubsection{Social representations}

We also witnessed examples of new and evolving social representations in the analyses of the narratives. While a detailed analysis is outside the scope of this paper, we provide couple of examples of anchoring and objectifying in new social representations [50]. When a male study participant said, "Access to pornographic material has never been this easy. I see this as a major cultural shift which is troubling," he is anchoring the new phenomena of access to pornographic material by naming it as "troubling cultural shift." When a male participant said, "The cell phone makes me live a life of fantasy and I feel that I am important because some women need me," he is objectifying his new experience of by attaching an emotional meaning of a "life of fantasy."

\subsection{Research and practical implications}

Much of IS research has concerned itself with organizational and end user issues. Research on societal impacts and in developing countries is nascent. In this regard, we make two main contributions. The theoretical framework presented in Fig. 2 is based on the much respected works of Amartya Sen and [36] Martha Nussbaum and is further enhanced by several theories in IS research. This framework can guide future researchers in several ways, e.g., (1) how artifacts and capabilities transform and metamorphose into capabilities, (2) how various theories like the affordance theory, social representation theory, agency theory, and structuration theory can help explain the process of transformation, and (3) are these theories sufficient or do we need to refine these theories to help improve our understanding of the phenomenon? The model we developed and as shown in Fig. 5 provides five dimensions of ICT impact on socio-economic development and can be the basis for future studies. One way will be to develop a positivist study, create an instrument with items for each dimension, and then empirically validate the instrument. Another venue for research will be to validate and compare these dimensions in different countries and cultures. 
In terms of practical utility of our results, stakeholders such as governments, public agencies, NGOs, and technology vendors can assess the real impacts of technology initiatives. For the technology manufacturers and vendors, their efforts should be directed to build technology and capabilities to enhance the customer experience and minimize the negative consequences. For the government and public decision-makers, they need to consider the citizens' perspectives in the formulation of ICT-related policies and programs.

\subsection{Limitations}

We will be remiss if we do not list the study's limitations. A natural limitation of a one-country study is its generalizabilty. While many of the concepts and observations may apply to other developing and Muslim nations, they should be viewed and interpreted with due care realizing that our sample of citizens is from Pakistan and it is only one of the many samples that could have been taken. Although we exercised much caution in attempting to obtain a representative sample, women were under-represented. The low participation of women is explained by the socio-cultural norms in Pakistan, which inhibit them from voicing their opinions. Another observation is the inherent subjectivity in qualitative research. The relatively large sample size, especially for qualitative research, and our best efforts in being objective in interpreting the narratives, should have minimized this bias. Finally, our results should not be treated as static or permanent because of the evolving nature of ICT and social processes. We fully expect that ICT issues and impacts will change over time; in fact, similar and repeated studies will be able to track such evolution.

\section{Conclusions}

This study explored the concept of ICT-driven socio-economic development, as perceived by ordinary citizens of a developing country. While several authors and pundits have described their own views of socio-economic development, the "people's" view is of paramount importance and cannot be ignored, given that it most directly affects their lives. Our research makes several contributions. We started out by creating a theoretical model of ICT's impacts on socioeconomic development. This model is an adaptation and extension of Amratya Sen's "capabilities approach" and applies it to the context of ICT. This model would provide numerous opportunities to future researchers in building on our work and further extending it. Using this model as the guiding force and utilizing the narrative qualitative methodology, we could generate several findings and a model of realized ICT impacts. The application of theory, appropriate qualitative methods, and the findings contribute to an enhanced understanding of socio-economic development in countries with similar economic, cultural, and religious background as Pakistan. Our results have implications and important consequences for governments, businesses, citizens, and other stakeholders. For example, the government and public decision-makers need to consider the citizens' perspectives in the formulation of policies and programs.

Appendix A. Summary of Backgrounds and Narratives of Select Participants

\begin{tabular}{|l|l|l|}
\hline Participant \# & Selection Criteria & Narratives Summary \\
\hline 1 & $\begin{array}{l}\text { Gender: Woman } \\
\text { Domicile: Rural } \\
\text { Education: Illiterate } \\
\text { Income: Medium }\end{array}$ & $\begin{array}{l}\text { This participant has a small cloth sale business in several nearby towns } \\
\text { close to her village. She travels as far away as 300 miles to buy cloth at } \\
\text { wholesale prices and sells at profit to villagers who cannot travel. Her } \\
\text { business has grown significantly since she got a cell phone. Her customers }\end{array}$ \\
\hline
\end{tabular}




\begin{tabular}{|c|c|c|}
\hline Participant \# & Selection Criteria & Narratives Summary \\
\hline & $\begin{array}{l}\text { 50-year-old } \\
\text { entrepreneur }\end{array}$ & $\begin{array}{l}\text { call her and tell what they want when she is traveling. Her personalized } \\
\text { service for customers has increased her revenues. She said: "I continuously } \\
\text { travel from one village to another and for buying wholesale cloth. My } \\
\text { customers love the fact that they can place 'special orders."” }\end{array}$ \\
\hline 2 & $\begin{array}{l}\text { Gender: Man } \\
\text { Domicile: Urban } \\
\text { Education: High School } \\
\text { Income: High } \\
\text { 35-year-old } \\
\text { entrepreneur }\end{array}$ & $\begin{array}{l}\text { This participant owns a small mechanical parts manufacturing facility in a } \\
\text { small urban area. The demand for his quality parts has grown steadily } \\
\text { between } 2003 \text { and } 2007 \text {. In late } 2007 \text {, he imported a used machine to } \\
\text { automate the manufacturing process. However, the machine had missing } \\
\text { parts and was not in operational condition. He used internet to find a } \\
\text { manual for this machine, made and fixed some parts, and brought the } \\
\text { machine to operational condition. The variation in production process has } \\
\text { gone down (0.0001\% rejection rate) and demand has increased significantly } \\
\text { ( } 800 \% \text { in one year). He uses internet, email, and cell phone to stay in touch } \\
\text { with his clients in different countries. He said, "I have no idea what I will } \\
\text { do without internet." He said, "My business has expanded several folds } \\
\text { since I started using a phone and email to keep in touch with my suppliers." }\end{array}$ \\
\hline 3 & $\begin{array}{l}\text { Gender: Woman } \\
\text { Domicile: Urban } \\
\text { Education: Graduate } \\
\text { Income: High } \\
\text { 50-year-old school } \\
\text { teacher }\end{array}$ & $\begin{array}{l}\text { Her children permanently live in the United States. She said, "I don't cry } \\
\text { anymore; I can speak with my children as much as I want without worrying } \\
\text { about the bill." Calls to the United States and most other countries do not } \\
\text { cost more than local call toll. She said she used to wait every weekend for } \\
\text { her children to call her. Now she can call whenever she wants. "I sometimes } \\
\text { see my children on a webcam as well," she said. This is one of the most } \\
\text { important changes that ICTs have brought in her life. }\end{array}$ \\
\hline 4 & $\begin{array}{l}\text { Gender: Man } \\
\text { Domicile: Rural } \\
\text { Education: Illiterate } \\
\text { Income: Low } \\
\text { 40-year-old honey } \\
\text { farmer }\end{array}$ & $\begin{array}{l}\text { He travels to find places with flowers for his bees. In addition to keeping in } \\
\text { touch with his family, he relies on his cell phone to find markets where he } \\
\text { can get best rates for his honey. He said, "I do not have to run around } \\
\text { anymore to find a better rate." Sometimes bees develop a deadly fungus. } \\
\text { He can immediately call someone to bring treatment for his bees from a far } \\
\text { off city. He said, "It is very expensive and difficult to raise bees once again } \\
\text { if they die due to fungus. I don't suffer those losses anymore because I can } \\
\text { get medication right away." }\end{array}$ \\
\hline 5 & $\begin{array}{l}\text { Gender: Man } \\
\text { Domicile: Urban } \\
\text { Education: Illiterate } \\
\text { Income: High } \\
\text { 38-year-old } \\
\text { entrepreneur }\end{array}$ & $\begin{array}{l}\text { This "illiterate mechanical engineer" was making a pulley system for a } \\
\text { machine that could be used in construction or agriculture businesses to fetch } \\
\text { loads or water. He said, "I got the idea from a TV program. I already have } \\
\text { a customer who will be using it in his construction business." Additionally, } \\
\text { he runs public transport system with } 5 \text { passenger vans. "I can keep in touch } \\
\text { with my employees and know exactly where they are when the van breaks } \\
\text { down and I have to go and fix it," he said. }\end{array}$ \\
\hline 6 & $\begin{array}{l}\text { Gender: Woman } \\
\text { Domicile: Urban } \\
\text { Education: Graduate } \\
\text { Income: Low } \\
\text { 24-year-old university } \\
\text { student }\end{array}$ & $\begin{array}{l}\text { "Initially, my parents did not allow me to go to Islamabad to study at one of } \\
\text { the premier universities in Pakistan," this participant said. Her parents were } \\
\text { concerned of her safety in a city as far away as } 500 \text { miles. However, things } \\
\text { changed when they got her a cell phone and found out that they could } \\
\text { always stay in touch with her. She said, "I probably would not be pursuing } \\
\text { higher education if I didn't have a cell phone and my parents didn't feel } \\
\text { that they can keep in touch with me anytime they wanted." She has access } \\
\text { to a large online library, which helps her in research and access to latest } \\
\text { publication on her areas of interest. She explained, "I use online library to } \\
\text { find research papers to support my literature review and research". }\end{array}$ \\
\hline 7 & $\begin{array}{l}\text { Gender: Man } \\
\text { Domicile: Rural } \\
\text { Education: Illiterate } \\
\text { Income: Medium } \\
\text { 23-year-old barber }\end{array}$ & $\begin{array}{l}\text { This participant works in his father's barber shop. He spends hours on } \\
\text { phone with prostitutes. His daily pocket money is Rs. } 20 \text {, but his daily cell } \\
\text { phone expense is Rs. } 500 \text {. To satisfy his addiction, he steals money from } \\
\text { the barber shop cash drawer. "I know it is wrong to steal money to pay for } \\
\text { my cell phone bill but I cannot help it," he said. "My father wants me to get }\end{array}$ \\
\hline
\end{tabular}




\begin{tabular}{|c|c|c|}
\hline Participant \# & Selection Criteria & Narratives Summary \\
\hline & & $\begin{array}{l}\text { married, but I have a lot of aspirations. I want to be famous and rich and } \\
\text { have a good life," he added. He explained, "The cell phone makes me live a } \\
\text { life of fantasy, and I feel that I am important because some women need me. } \\
\text { I know it is not considered good, but I cannot help it and don't know how to } \\
\text { stop it." }\end{array}$ \\
\hline 8 & $\begin{array}{l}\text { Gender: Woman } \\
\text { Domicile: Rural } \\
\text { Education: Illiterate } \\
\text { Income: Medium } \\
\text { 50-year-old housewife }\end{array}$ & $\begin{array}{l}\text { "I have seen a lot of girls and boys making out on phone and even deciding } \\
\text { on marrying without their parents' approval; this is very bad," this } \\
\text { participant said. This conservative woman in a village admits that cell } \\
\text { phones are very helpful in several aspects but does not want young girls and } \\
\text { boys to be carrying phones around just to waste time on "useless" talk. She } \\
\text { sees a major transformation in the social structure in rural areas where } \\
\text { parents are losing control over their children in young age because of cell } \\
\text { phones. }\end{array}$ \\
\hline 9 & $\begin{array}{l}\text { Gender: Woman } \\
\text { Domicile: Urban } \\
\text { Education: Graduate } \\
\text { Income: High } \\
\text { 45-year-old IT } \\
\text { administrator }\end{array}$ & $\begin{array}{l}\text { This participant accidently got involved in IT administration because of } \\
\text { good credentials in project management. "My boss did not give me a choice } \\
\text { and wanted me to head the IT department. I told him that I didn't know a } \\
\text { thing about computers, and he said, you can learn these things. I got a big } \\
\text { raise too." She explained, "I enjoy this job because I have learned a lot } \\
\text { here, but it has turned my family life upside-down." She carries her phone } \\
\text { with her when she is cooking food for her children just in case her services } \\
\text { are needed during network and IT services disruptions. }\end{array}$ \\
\hline 10 & $\begin{array}{l}\text { Gender: Man } \\
\text { Domicile: Urban } \\
\text { Education: Illiterate } \\
\text { Income: Medium } \\
\text { 34-year-old donkey } \\
\text { cart owner }\end{array}$ & $\begin{array}{l}\text { This participant hauls loads from warehouses to furniture showrooms when } \\
\text { someone makes a purchase in a showroom. "The owner of the showroom } \\
\text { would go peak out of his place to see if a donkey cart person was there," he } \\
\text { said. Then he got a cell phone. He cannot read... not even numbers (he } \\
\text { visually matches patterns for a phone number on a piece of paper and dial } \\
\text { pad of his phone when he needs to dial a number). He explained, "Someone } \\
\text { helped me with setting up the phone for distinctive ring tones. Showroom } \\
\text { owners give me a missed call, and I can recognize who needs my help by a } \\
\text { specific ring tone setup for a particular showroom owner. Now I can work } \\
\text { as much as I want". }\end{array}$ \\
\hline 11 & $\begin{array}{l}\text { Gender: Man } \\
\text { Domicile: Urban } \\
\text { Education: High School } \\
\text { Income: High } \\
\text { 27-year-old plumber }\end{array}$ & $\begin{array}{l}\text { "I started my plumbing business a few years ago. I rented a place to setup } \\
\text { my shop. I did a mediocre business," he said. He bought a cell phone in } \\
\text { 2007. Now he only puts his cell number on the business card. He } \\
\text { explained, "I do more business, and my customers never have to leave their } \\
\text { place to come see me. They just call me and I am there for service and } \\
\text { repair in a few minutes." His business has expanded significantly and costs } \\
\text { have gone down. He explained, "my costs of doing a business have gone } \\
\text { down because I don't need to rent a shop anymore." }\end{array}$ \\
\hline 12 & $\begin{array}{l}\text { Gender: Man } \\
\text { Domicile: Urban } \\
\text { Education: Graduate } \\
\text { Income: High } \\
\text { 39-year-old vice- } \\
\text { president of a software } \\
\text { development house }\end{array}$ & $\begin{array}{l}\text { This participant travels frequently to see his clients overseas in Europe and } \\
\text { the United States. "ICTs have changed my life; my life revolves around } \\
\text { these technologies," he said. He uses online meetings with his clients but } \\
\text { for major decisions such as signing of a large project or deliver final } \\
\text { product in a ceremonial manner, he travels for weeks away from his little } \\
\text { children, wife, and old parents. "When I am on a business trip abroad, I } \\
\text { can still see my 5- and 2-year-old girls on webcam, and they can see me } \\
\text { too; my mother does not feel that I am away because she can still see me } \\
\text { and speak with me every night before she goes to bed. ICT keep us united } \\
\text { even when we are physically apart," he added. }\end{array}$ \\
\hline
\end{tabular}

\section{References}


[1] R. Kozma, National policies that connect ICT-based education reform to economic and social development, Hum. Technol. 1 (2) (2005) 117-156.

[2] T. Irawan, ICT and economic development: comparing ASEAN member states, Int. Econ. Econ. Policy 11 (1-2) (2014) 97-114.

[3] J. Danzgler, Computers and the frustrated chief executive, MIS Q. 1 (2) (1977) 43-52.

[4] A. Hardy, The role of the telephone in economic development, Telecommun. Policy 4 (1) (1980) 278-286.

[5] W.J. Orlikowski, C.S. Iacono, Research commentary: desperately seeking the 'IT' in IT research-A call to theorizing the IT artifact, Inf. Syst. Res. 12 (2) (2001) 121-134.

[6] S. Puri, Integrating scientific with indigenous knowledge: constructing knowledge alliances for land management in India, MIS Q. 31 (2) (2007) 355-379.

[7] J.P.A. Hsieh, A. Rai, M. Keil, Understanding digital inequality: comparing continued use behavioral models of the socio-economically advantaged and disadvantaged, MIS Q. (2008) 97126.

[8] A. Chaudhuri, ICT for Development: solutions seeking problems \& quest, J. Inf. Technol. 27 (4) (2012) 326-338.

[9] E.J. Liew, S. Vaithilingam, M. Nair, Facebook and socio-economic benefits in the developing world, Behav. Inf. Technol. 33 (4) (2014) 345-360.

[10] T. Donaldson, L.E. Preston, The stakeholder theory of the corporation: concepts, evidence, and implications, Acad. Manage. Rev. 20 (1) (1995) 65-91.

[11] A. Sen, Development as freedom, Oxford Paperbacks, 2001.

[12] G. Jacobs, R. Macfarlane, N. Asokan, Towards a Comprehensive Theory of Social Development, Human Choice, World Academy of Art \& Science, 1999 Retrieved from http://www.icpd.org/development theory/comprehensive theory of social development.htm on January 21, 2010.

[13] Oxford English Dictionary, (2010). Retrieved from http://www.oed.com/on January 19, 2010.

[14] W.W. Rostow, The Stages of Economic Growth: A Non-Communist Manifesto, Cambridge University Press, Cambridge, 1990.

[15] S. Amin, Unequal Development: An Essay on the Social Formations of Peripheral Capitalism, Monthly Review Press, New York, 1976. 
[16] I. Wallerstein, World-systems Analysis: An Introduction, Duke University Press, Chapel Hill, 2001.

[17] P. Preston, Development Theory: An Introduction to the Analysis of Complex Change, Wiley-Blackwell, Oxford, 1996.

[18] L. Abbott, Theories of Industrial Modernization and Enterprise Development: A Review, Industrial Systems Research Publications, Manchester, 2002.

[19] A. Szirmai, The Dynamics of Socio-economic Development: An Introduction, Cambridge University Press, Cambridge, 2005.

[20] D. Houtman, Class and Politics in Contemporary Social Science: 'Marxism Lite' and Its Blind Spot for Culture, Aldine Transaction, New Jersey, 2004.

[21] E.J. Blakely, Community Development Research: Concepts, Issues, and Strategies, Human Sciences Press, New York, 2000.

[22] World Bank, Glossary, (2014) http://www.worldbank.org/depweb/english/beyond/global/glossary.html.

[23] A. Lewis, Economic development with unlimited supplies of labour, The Manchester School 22 (2) (1954) 139-191.

[24] A. Choudhury, S. Zaman, S. Harahap, An evolutionary topological theory of participatory socioeconomic development world futures, J. Gen. Evol. 63 (8) (2007) 584-598.

[25] A. Ramos, Social values dynamics and socio-economic development, Port. J. Soc. Sci. 5 (1) (2006) 35-64.

[26] D. Goldsworthy, Thinking politically about development, Dev. Change 19 (3) (1988) 505536.

[27] J. Gallup, Geography and Socioeconomic Development, Background Paper Examining the State of the Andean Region for the Andean Competitiveness Project, (2000) Retrieved from http://www.cid.harvard.edu/archive/andes/documents/bgpapers/geography socioeconomicdevelo pment.pdf on January 102010.

[28] R.B. Potter, T. Binns, J.A. Elliott, D. Smith, Geographies of Development, Prentice Hall, New York, 2004.

[29] J. Kaivo-oja, P. Rikkonen, Key issues for successful scenario planning: perspectives on sustainable use of natural resources in agricultural sector. Sustainable use of renewable natural resources-from principles to practices/Anneli Jalkanen \& Pekka Nygren (toim.), 2005. 
[30] S. Ahmed, A. Adams, M. Chowdhury, A. Bhuiya, Gender, socioeconomic development and health-seeking behavior in Bangladesh, Soc. Sci. Med. 51 (3) (2000) 361-371.

[31] S. Madon, The Internet and socioeconomic development: exploring the interaction, Inf. Technol. People 13 (2) (2000) 85-101.

[32] D. Thapa, Ø. Sæbø, Exploring the link between ICT and development in the context of developing countries: a literature review, Electr. J. Inf. Syst. Dev. Ctries. (2014) 64.

[33] B.S. Gigler, Informational capabilities: the missing link for understanding the impact of ICT on development, Closing Feedback Loop (2014) 17.

[34] S. Madon, Evaluating the developmental impact of E-governance initiatives: an exploratory framework, Electr. J. Inf. Syst. Dev. Ctries. 20 (5) (2005) 1-13.

[35] C. Avgerou, Information systems in developing countries: a critical research review, J. Inf. Technol. 23 (3) (2008) 133-146.

[36] M.C. Nussbaum, Capabilities and human rights, Fordham L. Rev. 66 (1997) 273.

[37] Y. Zheng, Different spaces for e-development: what can we learn from the capability approach? Inf. Technol. Dev. 15 (2) (2009) 66-82.

[38] I. Robeyns, The capability approach: a theoretical survey, J. Hum. Dev. 6 (1) (2005) 93117.

[39] G. Walsham, Interpretive case studies in IS research: nature and method, Eur. J. Inf. Syst. 4 (1995) 74-81.

[40] K.M. Eisenhardt, Building theories from case study research, Acad. Manag. Rev. 14 (4) (1989) 532-550.

[41] S.L. Pan, B. Tan, Demystifying case research: a structured-pragmatic-situational (SPS) approach to conducting case studies, Inf. Organ. (2011) 161-176.

[42] A. Sen, Capability and Well-being, (1993).

[43] A. Giddens, The Constitution of Society: Outline of the Theory of Structure, (1984) Berkeley.

[44] M.R. Jones, H. Karsten, Giddens's structuration theory and information systems research, Mis Quarterly 32 (1) (2008) 127-157.

[45] P.M. Leonardi, When flexible routines meet flexible technologies: affordance, constraint, and the imbrication of human and material agencies, MIS Q. 35 (1) (2011) 147-167. 
[46] S. Moscovici, Social Representations: Explorations in Social Psychology, in: G. Duveen (Ed.), Polity, Cambridge, 2000, pp. 18-77.

[47] M.C. Boudreau, D. Robey, Enacting integrated information technology: a human agency perspective, Organ. Sci. 16 (1) (2005) 3-18.

[48] S. Moscovici, Attitudes and opinions, Annu. Rev. Psychol. 14 (1963) 231-260.

[49] A. Sen, Capabilities lists and public reason: continuing the conversation, Feminist Econ. 10 (3) (2004) 77-80.

[50] B. Hoïjer, Social representations theory. a new theory for media research, Nordicom Rev.: Nordic Res. Media Commun. 32 (2) (2011) 3-16.

[51] W.J. Orlikowski, J.J. Baroudi, Studying information technology in organizations: research approaches and assumptions, Inf. Syst. Res. 2 (1) (1991) 1-28.

[52] J.W. Cresswell, Qualitative Inquiry and Research Design, third edition, Sage, Thousand Oaks, 2013.

[53] B. Chae, M.S. Poole, The surface of emergence in systems development: agency, institutions, and large-scale information systems, Eur. J. Inf. Syst. 14 (1) (2005) 19-38.

[54] D. Joseph, N. Kok-Yee, C. Koh, A. Soon, Information technology professionals: a narrative review, meta-Analytic structural equation modeling, and model development, MIS Q. 31 (3) (2007) 547-577.

[55] E. Bartis, N. Mitev, A multiple narrative approach to information systems failure: a successful system that failed, Eur. J. Inf. Syst. 17 (2) (2008) 112-123.

[56] K. Casey, The new narrative research in education, Rev. Res. Educ. 21 (1995:1996) (1996) 211-253.

[57] K. Casey, I Answer with My Life: Life Histories of Women Teachers Working for 58] M. Murray, Connecting narrative and social representation theory in health research, Soc. Sci. Inf. 41 (4) (2002) 653-673.

[59] C.K. Riessman, Narrative Analysis, SAGE Publications, New York, 1993.

[60] A. Peshkin, In search of subjectivity One’s own, Educ. Res. 17 (7) (1988) 17-21.

[61] A. Sen, Well-being, agency and freedom: the Dewey lectures 1984, J. Philos. 82 (4) (1985) 169-221.

[62] S.Y. Imtiaz, M.A. Khan, M. Shakir, Telecom sector of Pakistan: potential, challenges and business opportunities, Telemat. Inform. 32.2 (2015) 254-258. 
[63] M.N. Baqir, S. Parvez, IT policy, Comput. News (2000) 15-31.

[64] Y.H. Mujahid, Digital opportunity initiative for Pakistan, Electr. J. Inf. Syst. Dev. Ctries. $8: 6(2002) 1-14$.

[65] P. Gao, A. Rafiq, The transformation of the mobile telecommunications industry in Pakistan: a developing country perspective, Telecommun. Policy (2009).

[66] C. Urquhart, H. Lehmann, M.D. Myers, Putting the 'theory'back into grounded theory: guidelines for grounded theory studies in information systems, Inf. Syst. J. 20 (4) (2010) 357381.

[67] Central Board of Revenue, Accessedon January 12, 2008 from www.cbr.gov.pk.

[68] K. Saidi, L.B. Hassen, M.S. Hammami, Econometric analysis of the relationship between ICT and economic growth in Tunisia, J. Know. Econ. 6 (4) (2015) 1191-1206.

[69] C.M. Olszak, E. Ziemba, The use of ICT for economic development in Silesian region in Poland, Interdiscip. J. Inf. Know. Manag. 6 (2011) 197-216.

[70] S. Rahim, S. Tie, A. Begum, Diffusion of ICT in Rural Areas Community for SocioEconomic Development Under the Platform of E-CLRC, (2014).

[71] M. Skryabin, J. Zhang, L. Liu, D. Zhang, How the ICT development level and usage influence student achievement in reading, mathematics and science, Comput. Educ. 85 (2015) 49-58.

Dr. Prashant Palvia is a Joe Rosenthal Excellence Professor in the Bryan School of Business \& Economics at the University of North Carolina at Greensboro, USA. He served as Department Head from 2000 to 2004, Information Systems PhD Program Director from 2003 to 2008, and the McDowell Research Center Director from 2007 to 2011. Prior to 30 years in academics, he had 9 years of industry experience. He received his PhD, MBA, and MS from the University of Minnesota and BS from the University of Delhi, India. Eighteen PhD students have written their dissertations under his guidance. He received UNCG's senior research excellence award in 2005. He has extensively worked in the field of Global Information Technology Management (GITM) and chairs the annual GITMA world conference, the next one being in Philadelphia, USA in June 2014 (http://www.gitma.org). He also chaired the EMR Implementation conferences at UNCG in 2010 and 2011. Professor Palvia is the Editor-in-Chief of the Journal of Global Information Technology Management, is the Associate Editor for Information \& Management, and is on the editorial board of several journals. His research interests include global information technology management, healthcare IT, security and privacy, virtual teams, electronic and mobile commerce, and media choice theory. He has published 106 journal articles, which include such outlets such as the MIS Quarterly, Decision Sciences, Communications of the ACM, Communications of the AIS, Information \& Management, Decision Support Systems, and ACM Transactions on Database Systems; and has published 210 conference articles. He has co-edited 
four books on Global Information Technology Management. Recently, he formed an international research team and launched the "World IT Project,", which looks at important IT issues in over 40 countries across the world.

Dr. Naveed Baqir serves as Chief Technology Architect at TechXponent Inc. and is currently implementing information risk management governance initiatives to safeguard protected health information of eight million members at a large healthcare company in Philadelphia. He has served as Chief Information and Technology Officer at Star Restaurant Group, LLC in Washington DC with background in systems development in banking, telecommunication and healthcare. He earned his Ph.D. in Information Systems from the University of North Carolina at Greensboro in 2009. In addition, Dr. Baqir holds an MBA, MS in Technology, MSc in Computer Science, and BSc in Mathematics and Physics.

Dr. Hamid Nemati is an Associate Professor of Information Systems at the University of North Carolina at Greensboro. He holds a doctorate degree from the University of Georgia and a MBA from The University of Massachusetts. He has extensive professional experience a developer and an analyst and has consulted with several major corporations. He has published nine books and over 100 peer reviewed academic publications in various premier scholarly and professional journals and conference proceedings. He is internationally recognized for his research in business analytics, big data, information security and privacy, organizational and behavioral aspects of Information Technology development and use. 